Florida International University

FIU Digital Commons

FIU Electronic Theses and Dissertations

University Graduate School

$11-12-2015$

\title{
Regional evolutionary distinctiveness and endangerment as a means of prioritizing protection of endangered species
}

Emily K. Brantner

ebran020@fiu.edu

DOI: $10.25148 /$ etd.FIDC000161

Follow this and additional works at: https:// digitalcommons.fiu.edu/etd

Part of the Biodiversity Commons, Biology Commons, and the Other Ecology and Evolutionary Biology Commons

\section{Recommended Citation}

Brantner, Emily K., "Regional evolutionary distinctiveness and endangerment as a means of prioritizing protection of endangered species" (2015). FIU Electronic Theses and Dissertations. 2267.

https://digitalcommons.fiu.edu/etd/2267

This work is brought to you for free and open access by the University Graduate School at FIU Digital Commons. It has been accepted for inclusion in FIU Electronic Theses and Dissertations by an authorized administrator of FIU Digital Commons. For more information, please contact dcc@fiu.edu. 


\title{
FLORIDA INTERNATIONAL UNIVERSTIY
}

Miami, Florida

\section{REGIONAL EVOLUTIONARY DISTINCTIVENESS AND ENDANGERMENT AS A MEANS OF PRIORITIZING PROTECTION OF ENDANGERED SPECIES}

\author{
A thesis submitted in partial fulfillment of the \\ requirements for the degree of \\ MASTER OF SCIENCE \\ in \\ BIOLOGY \\ by
}

Emily K. Brantner

2015 
To: Dean Michael R. Heithaus

College of Arts and Sciences

This thesis, written by Emily K. Brantner, and entitled Regional Evolutionary Distinctiveness and Endangerment as a Means of Prioritizing Endangered Species, having been approved in respect to style and intellectual content, is referred to you for judgment.

We have read this thesis and recommend that it be approved.

Maureen A. Donnelly

Kenneth J. Feeley

John C. Withey, Major Professor

Date of Defense: November 6, 2015

The thesis of Emily K. Brantner is approved.

Dean Michael R. Heithaus

College of Arts and Sciences

Dean Lakshmi N. Reddi

University Graduate School

Florida International University, 2015 


\section{ACKNOWLEDGMENTS}

I wish to thank my thesis committee for not only helping me to complete this document successfully, but also for helping me come to the decision to change paths and make those changes smoothly. Their support and belief in me kept me going until I had it finished. Dr. Maureen Donnelly gave so much encouragement that not finishing was never even a possibility, and Dr. Kenneth Feeley helped to push the project into a more clear and concise direction. I would especially like to thank Dr. John Withey. Without his help and guidance, I would have been stuck at many points along the way. He was always there to talk about the direction that I wanted to take, and then to help me find a way to get there. I also wish to thank Dr. Erik Nelson of Bowdoin College for providing the summarized cost data tables used, as well as Dr. Will Pearse for his help in my learning how to use phylogenetic trees.

I also wish to thank Florida International University for the teaching assistantship that allowed me to make ends meet while I pursued the completion of this thesis. 


\begin{abstract}
OF THE THESIS
REGIONAL EVOLUTIONARY DISTINCTIVENESS AND ENDANGERMENT AS A MEANS OF PRIORITIZING ENDANGERED SPECIES

by
\end{abstract}

Emily K. Brantner

Florida International University, 2015

Miami, Florida

Professor John C. Withey, Major Professor

Conservation is costly, and choices must be made about where to best allocate limited resources. I propose a regional evolutionary diversity and endangerment (REDE) approach to prioritization of endangered species. It builds off of the evolutionary diversity and global endangerment (EDGE) approach, but will allow conservation agencies to focus their efforts on species in specific regions. I used the RED-E approach to prioritize mammal and bird species listed under the U.S. Endangered Species Act (ESA), as well as to make a ranking of species without ESA critical habitat $(\mathrm{CH})$, as a practical application. Regional conservation approaches differ significantly from global approaches. The RED-E approach places a high significance on the level of endangerment of a species, but also allows for very distinct species to have increased prioritization on the RED-E list. Using the CH RED-E list, the U.S. government could begin focusing resources toward endangered and genetically diverse species. 


\section{TABLE OF CONTENTS}

CHAPTER

PAGE

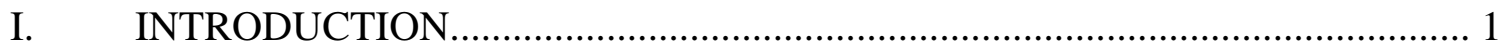

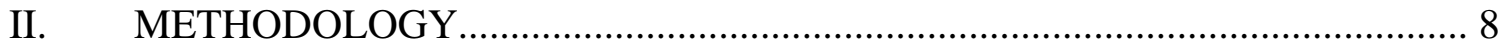

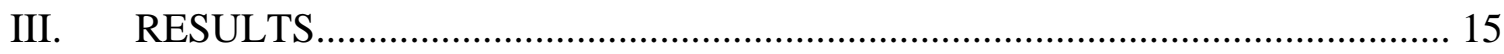

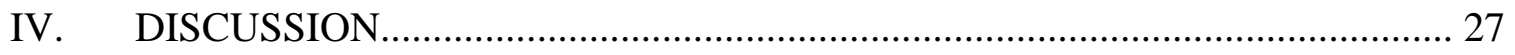

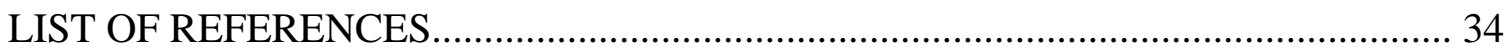

APPENDICES 


\section{LIST OF FIGURES}

FIGURES

PAGE

1. HOW TO CALCULATE EVOLUTIONARY DISTINCTIVENESS........................ 9

2. REGIONAL EVOLUTIONARY DISTINCTIVENESS AND ENDANGERMENT VERSUS GLOBAL EVOLUTIONARY DISTINCTIVENESS AND

ENDANGERMENT IN MAMMALS.............................................................. 16

3. REGIONAL EVOLUTIONARY DISTINCTIVENESS AND ENDANGERMENT VERSUS GLOBAL EVOLUTIONARY DISTINCTIVENESS AND ENDANGERMENT IN BIRDS.

4. GLOBAL TO REGIONAL ENDANGERMENT AND GLOBAL TO REGIONAL EVOLUTIONARY DISTINCTIVENESS IMPACT (MAMMALS) ........................... 18

5. GLOBAL TO REGIONAL ENDANGERMENT AND GLOBAL TO REGIONAL EVOLUTIONARY DISTINCTIVENESS IMPACT (BIRDS)................................. 19

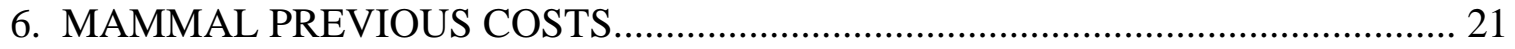

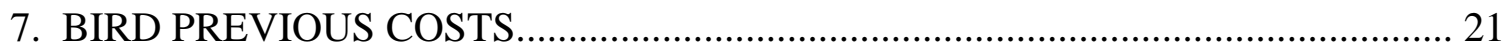




\section{ABBREVIATIONS AND ACRONYMS}

$\begin{array}{ll}\text { EH } & \text { Critical habitat } \\ \text { EDAM } & \text { Evolutionary distinctiveness } \\ & \text { Evolutionary distinctiveness with accuracy and magnitude } \\ \text { EDGE } & \text { Evolutionary distinctiveness and global endangerment } \\ \text { ESA } & \text { Endangered Species Act } \\ \text { FWS } & \text { Fish and Wildlife Service } \\ \text { GE } & \text { Global endangerment } \\ \text { IUCN } & \text { International Union for Conservation of Nature } \\ \text { NMFS } & \text { National Marine and Fisheries Services } \\ \text { PD } & \text { Phylogenetic diversity } \\ \text { RE } & \text { Regional endangerment } \\ \text { RED } & \text { Regional evolutionary distinctiveness } \\ \text { RED-E } & \text { Regional evolutionary distinctiveness and endangerment }\end{array}$




\section{INTRODUCTION}

Biodiversity loss

Species extinctions are a cause for alarm due to resultant decreases in diversity and ecosystem services. On June 16, 2015 the US Fish and Wildlife Service (FWS) declared the Eastern cougar (Puma concolor couguar), previously ranging from Maine to South Carolina, and as far West as Tennessee and Michigan, to be extinct (FWS 2015b, Cardoza \& Langlois 2002). Only the Western cougar and the Florida panther are left to represent the big cats of the United States. In 2005, the IUCN declared the Solomon Island's thick-billed ground dove (Gallicolumba salamonis) extinct. Amphibians everywhere are facing mass extinction, so much so that it has been deemed the "sixth mass extinction” (Wake \& Vredenburg 2008). Human-mediated changes to species habitats such as habitat loss, climate change, invasive species, overexploitation, and synergistic effects between them (Brook et al. 2008), add up to a current annual extinction rate of 27,000 species per year, or one species every twenty minutes (Wilson 1992), as estimated by species-area relationships (May \& Stork 1995). These calculations have been criticized as overestimating extinction by some (Pimm 1998, Grelle et al. 1999, Cowlishaw 1999), but have held up well if calculated at an appropriate scale. As habitats are altered and climate changes, the resultant losses of biodiversity are of increasing concern for both scientific communities and government bodies (Purvis \& Hector 2000), but the strategies used for conserving biodiversity are controversial (Millenium 2005, Butchart et al. 2010).

All conservation efforts have associated costs, from the opportunity cost of land protected from development, to the cost of restoration and/or management for habitat in a 
previously developed or degraded landscape, to the costs of land acquisition for new protected areas. Because of these costs, it may not be feasible to fully protect all species in all places. The inability to protect all species is the basis for the "Noah's Ark" analogy: only so many species can fit on the 'conservation boat,' and some system of prioritization must be used to decide which species to conserve (Weitzman 1998). While a ranking system may seem straight forward, there are many different factors to consider when ranking species (Metrick \& Weitzman 1998). Do we conserve flora and fauna on the basis of aesthetic appeal? Functionality? Rarity? Distinctiveness? Cost of conservation? An amalgamation of some or all of these characteristics?

From a biological standpoint, retaining maximal genetic variability should be a priority in any conservation plan. Conserving genetic variability is important due to its association with functional diversity or evolutionary potential, and to a lesser extent, for its association with species rarity (Winter et al. 2012). Rare species, by their very nature, are often at the greatest risk of extinction (Arponen 2012). Rarity can also be accompanied by greater genetic uniqueness, which could lead to unique functional traits that allow for survival in extreme conditions, or allow the species to approach an obstacle differently than other species in the same habitat (Winter et al. 2012). Losing genetically distinct species could also cut off evolutionary potential, as a unique species may be one that adapts more quickly, which will be particularly important in the face of climate change (Winter et al. 2012).

On the other hand, evolutionary potential as an argument for maintaining genetic diversity lacks empirical evidence, as it is unknown whether a species belongs to an old clade or a young clade that has recently radiated (Mouquet et al. 2012). Even with 
species loss as drastic as $95 \%$ of total species on the planet, $80 \%$ of the current phylogenetic diversity (PD) would remain (McKinney 1998). Phylogenetic diversity is defined as the cladistic relationships among species or taxa (Faith 1993), or ancestral genetic information, and much of that information can be conserved by other species within a given clade (Nee \& May 1997). Unfortunately, current extinction patterns are not random (Mace \& Balmford 1999, Bennett \& Owens 1997, McKinney 1997, Russell et al. 1998), with many related species being wiped out together, and non-random extinction models do not protect phylogenetic diversity (Heard \& Mooers 2000).

When faced with the current selective extinction, or extinction biased toward certain phylogenetic groups, the ability to avoid losses of entire clades is greatly reduced (McKinney 1998, Purvis et al. 2000). Because conserving species can be costprohibitive, maintaining species across the phylogenetic tree should be prioritized because it affects ecosystem function (Cadotte et al. 2012). For example, plots with plant species that are distantly, yet evenly related to each other are more stable than plots with only closely related species growing together (Cadotte et al. 2012). Conservation focus should be turned toward evolutionarily distinct species, in order to conserve more branches of the tree of life in the long run (Heard \& Mooers 2000).

\section{Phylogenetic distinctiveness as a measure for conservation}

There are many measures of biodiversity that have been proposed for use in conservation. These measures can fall into categories of preserving the individual, the species, the community, ecosystem, and so on (Weitzman 1993, Winter et al. 2013). One measure of a species' uniqueness is evolutionary distinctiveness (ED). Evolutionary 
distinctiveness is the phylogenetic diversity of a clade split equally among its members, taking each branch length for all species into account. The value is calculated as the “sum of the values per branch” (Isaac et al. 2007). Evolutionary distinctiveness correlates positively with other common biodiversity measures such as species richness and species diversity (Polasky et al. 2001).

Evolutionary distinctiveness (ED) is not enough to prioritize a species for conservation. If a species is not in any danger of extinction, it would not make sense to spend limited resources protecting it. A commonly used method to incorporate a measure of endangerment into a ranking of ED is the "EDGE" approach (Isaac et al. 2007), which adds how globally endangered (GE) a species is according to the IUCN Red List. The EDGE approach has been cited positively almost 200 times in Web of Science, and the rate of citations is increasing. It has been applied to mammals, birds, and amphibians (Isaac et al. 2007, Isaac et al. 2012, Redding \& Moores 2006, Jetz et al. 2014). A newly proposed way to add a measure of endangerment is to add the accuracy with which decline can be determined (A) and the magnitude of said decline (M) to calculate and "EDAM" value (Pearse et al. 2014). The EDAM value is shown to be more useful when looking at specific countries than the EDGE value, which relies solely on the IUCN's global database and may overlook a species unlisted by the IUCN, which may actually have related species or populations that are critical to an ecosystem in one particular area. The EDAM value, while a better indicator for specific areas than EDGE, uses factors that are difficult to quantify and compile, making it less useful for government agencies, which may not have the personnel or resources to gather those data (Pearse et al. 2014). 
Because many countries have their own listings created separately from IUCN categories, I propose to form a RED-E value, or Regional Evolutionary Distinctiveness and Endangerment. The RED-E approach will perform essentially the same purpose as EDGE, but allow for government agencies or other organizations to use their own local categories of endangerment, and phylogenetic trees trimmed to only their country or region of interest, in order to prioritize species more appropriately as compared to using the global endangerment status and species pool. Using RED-E also reduces the number of species that need to be considered, and if a government can focus on smaller, regional or national lists of species, they may be more likely to act than if they are faced with larger, overwhelming lists of species. I will detail how to use the RED-E listing with any number of listing measurements to make a simple ranking of species determined by distinctiveness and endangerment in a given area. I will also quantify previous conservation attention as the amount of money spent on protecting listed species in the U.S., and compare that to the RED-E ranking.

\section{ESA/Critical Habitat}

The Endangered Species Act (ESA) is pivotal to protecting and listing species of concern within the United States of America. The ESA created a two-tier ranking system to classify how perilous the situation is for a given listed species. The lower-peril status is “threatened," defined as "any species which is likely to become an endangered species within the foreseeable future throughout all or a significant portion of its range.” The higher-peril status is “endangered,” defined as "any species which is in danger of extinction throughout all or a significant portion of its range,” except in the case of pest 
insects. I use the species found within the continental United States as our species pool for calculating regional ED, and ESA-listed species as our measure of endangerment.

The ESA listing protects included species from “take,” or to "harass, harm, pursue, hunt shoot, wound, kill, trap, capture, or collect, or attempt to engage in any such conduct,” on any private or public land (Department of the Interior, U.S. Fish and Wildlife Services 1973). Critical habitat (CH) area is an additional regulatory measure that designates a geographical area where no federal agencies may conduct or permit actions that will destroy or harm an ESA listed species (Department of the Interior, U.S. Fish and Wildlife Services 1973). Individuals with land in the CH area may recognize the importance of that area for conservation and avoid any take of the species within that area, whether out of concern for conservation or to stay out of legal trouble (Suckling \& Taylor, 2005). According to the ESA, if a species is listed as threatened or endangered, $\mathrm{CH}$ should be designated "to the maximum extent prudent and determinable (FWS 2015).” Unfortunately, many species listed as threatened or endangered have been left without CH designation (Table 1).

Table 1: Percentage of listed species within each group with critical habitat designation (FWS 2015).

\begin{tabular}{lr}
\multicolumn{1}{c}{ Percent listed species with Critical Habitat (N of species) } \\
\hline Non-flowering Plants & $45.7 \%(37)$ \\
Flowering Plants & $47.2 \% 856)$ \\
Invertebrates & $44.8 \%(259)$ \\
Vertebrates & $39.6 \%(442)$ \\
$\quad$ Fishes & $47.6 \%(164)$ \\
Amphibians & $45.7 \%(35)$ \\
Reptiles & $37.5 \%(40)$ \\
$\quad$ Birds & $29.0 \%(100)$ \\
Mammals & $35.9 \%(103)$
\end{tabular}


As a practical example of how to use RED-E values, I propose to compile a REDE list to recommend which species of mammals and birds should be prioritized for $\mathrm{CH}$ designation, and compare that against the global EDGE approach.

\section{Critical Habitat: Criticisms}

While the law requires critical habitat, there is much debate over whether it is useful in conservation (Corn et al. 2012). Although the ESA is required to designate critical habitat to all listed species, they often fail or are slow to do so (to date it has taken a median of 3.1 [mean $=5.1]$ years to designate a final critical habitat for those species with critical habitat areas, with a maximum delay of 30 years; Nelson et al. 2015). The Fish and Wildlife Service (FWS) and the National Marine Fisheries Service (NMFS) believe that critical habitat designations may not afford any more protection to listed species than those that fall under the rest of the ESA regulations. They argue that the cost of designating critical habitat is not worth the presumably small or non-existent advantage to the listed species (Corn et al. 2012). Species with critical habitat designation have shown better recovery scores than species without (Taylor et al. 2005, Suckling and Taylor 2005), but it is unknown how much of that score can be attributed to the presence of critical habitat. Overall, little research has been done in this area. 


\section{METHODOLOGY}

\section{Data collection}

I retrieved a file with three mammal composite phylogenetic 'supertrees' in nexus format from Beninda-Emonds (2007). The file included trees in agreement with upper date limits, lower date limits, and best date limits, but contains only 4510 of 4548 species described (Wilson \& Reeder 2005). I retrieved one thousand possible bird trees from http://birdtree.org/ in a .tre format (Jetz et al. 2012). All trees were used to calculate global EDGE scores and then trimmed to only continental US species to calculate RED-E scores. Only extant, non-introduced species were included in the trimmed trees.

\section{Mammal evolutionary distinctiveness}

I processed the mammal phylogenetic trees using the package 'ape' to open the trees, and the package 'caper' to run calculations in R 3.1.2 (Orme 2013, R 2013). Caper's ed.calc function calculates the evolutionary distinctiveness (ED) for each species, which is a number that indicates each individual species' relatedness to all other species in a given tree. 


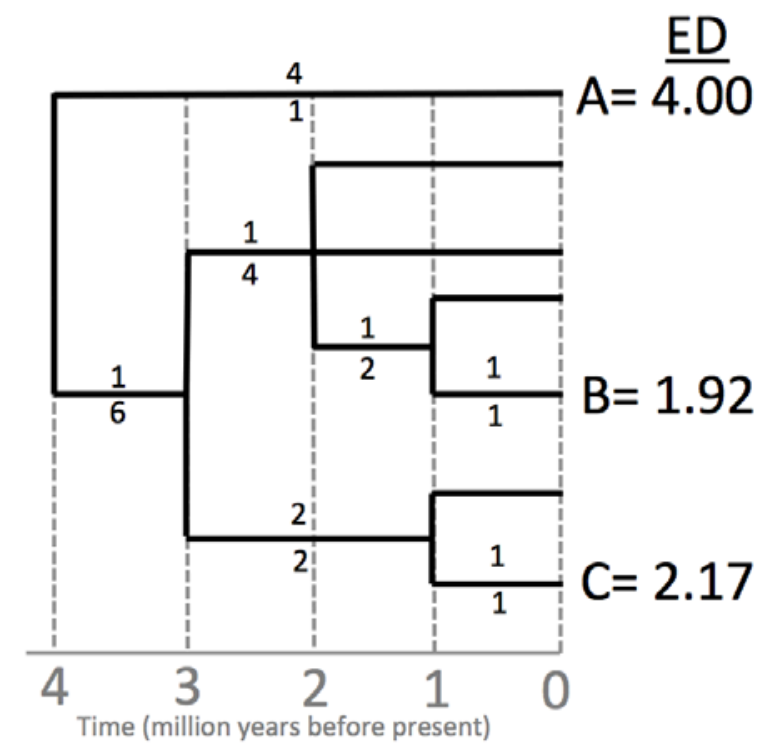

Figure 1. HOW TO CALCULATE EVOLUTIONARY DISTINCTIVENESS: Example clade to show evolutionary distinctiveness (ED) calculation. The numbers above and below each branch are the length of each branch in millions of years (MY) and the number of species arising from it, respectively. Added together as fractions, they equal the ED listed beside each hypothetical species. Following Figure 1 in Isaac et al. (2007).

Evolutionary distinctiveness is calculated as the sum of each of the branches, with each branch represented by the number of million years (MY) that it extends, over the number of species branching off of that ancestral species (Figure 1). In the example clade depicted in Figure 1, species A has one known species on the entire terminal branch, over 4 million years (MY), giving it an ED of 4/1 $=4$. Species B has 1 species at the terminal branch over $1 \mathrm{MY}$, then 2 species branching from the next node over $1 \mathrm{MY}$, 4 species over the next $1 \mathrm{MY}$, and 6 species over the next $1 \mathrm{MY}$, leading us to the final node. The branches, summed together would give an ED of $(1 / 1+1 / 2+1 / 4+1 / 6)=$ 1.92. Species C, following the same method, gives and ED of $(1 / 1+2 / 2+1 / 6)=2.17$. Ranked in order of most evolutionary distinct, the list by ED value would be A, C, then B. 
Because some species are missing from the mammal tree, it could raise the ED score of mammals closely related to the missing species, but none of the species listed by the ESA fell under the category of 'closely related.' Most of the ED comes from branches near the tips, so any effects of those missing species would be negligible (Isaac et al. 2007). I calculated the ED for all species from the upper, lower, and best date trees, and then took the geometric mean for each species as the final global ED, following the protocol set by Isaac et al. (2007).

I compiled a list of mammal species in the US by combining the information found from the American Society of Mammologists and the Smithsonian National Museum of Natural History (ASM 2015, Smithsonian 2015). After creating a database of the continental US species, I used the drop.tip function in caper to remove all species that were not in our database out of the original 4510 species in the upper, best, and lower date trees. I ran ed.calc on the remaining 356 continental US species for all three trees again, and found the geometric mean for each species as the final regional evolutionary distinctiveness (RED) for each species (see supplemental data for R code).

\section{Bird evolutionary distinctiveness}

I used caper to calculate the global ED for each of the 9993 species in all 1000 trees, then averaged them to find the ED for each species. I used caper's drop.tip function to drop all species not found in the continental US, as compiled from the World Institute for Conservation and Environment (WICE 2015) in 1000 possible trees. I excluded all species that were extinct, rarely seen, or not verified to have actually been in the US from our analysis of US species. I then recalculated the ED for all 719 species 
left in the trimmed trees, and averaged the ED values from 1000 trees for a given species to obtain its RED value (see supplemental data for R code).

\section{GE and RE calculation}

I used the ED values as calculated above for every species of mammals and birds listed under the Endangered Species Act, and removed all that were not in the continental US. Unlike the phylogenetic data, which only go to the species level, the ESA includes subspecies and populations (or evolutionarily distinctive units, ESUs). Those species that are split into subspecies and populations by the ESA will have the same ED but may differ in ESA threat level, which would affect our "regional evolutionary distinctiveness and endangerment,” or RED-E, value. I allowed the subspecies and populations to remain separate in our rankings to further show the differences between global and regional rankings.

The IUCN rankings of 'least concern,' 'near threatened,' 'vulnerable,' 'endangered,' and 'critically endangered' were assigned a rank of zero, one, two, three, and four, respectively (IUCN 2014), while ESA ‘threatened' was ranked as a two and 'endangered' as a four. The IUCN numbers represent a global endangerment (GE) value, while the ESA numbers represent a regional endangerment (RE) value. Three species, the Killer Whale (Orcinus orca), Spotted Seal (Phoca largha), and False Killer Whale (Pseudorca crassidens) were rated DD, or data deficient, by the IUCN and were not used in my analysis. The ESA listed some species as SAT or SAE, and are "threatened due to similar appearance.” They are listed to keep people from “taking” a listed species because they thought it was a different, similar species. Only two mammal species, the 
puma (Puma concolor) and the American black bear (Ursus americanus luteolus), had rankings of SAT, and I treated both as 'threatened.'

\section{RED-E and EDGE rankings}

I calculated the global ED with global endangerment values (EDGE; Isaac 2007) using the following formula:

$$
E D G E=\ln (1+E D)+G E * \ln (2)
$$

which gives a log scale representation of extinction risk (Isaac 2007).

I calculated the regional ED and endangerment (RED-E) with the equation:

$$
R E D-E=\ln (1+R E D)+R E * \ln (2)
$$

that gives us a regional view of extinction risks.

I used both the EDGE and RED-E extinction risk numbers to create four ranked lists of continental US, ESA listed species: mammal EDGE, mammal RED-E, bird EDGE, and bird RED-E. I compared the two approaches by regressing the RED-E scores against the EDGE scores for each group.

\section{Statistics}

Because EDGE and RED-E were calculated using phylogenetic trees with differing branch numbers, the EDGE and RED-E scores cannot be compared directly. Instead, to find whether changing from global ED to regional ED or changing from global endangerment to regional endangerment had significant effects on the scores, I used the number of standard deviations away from the mean as a standardized value for both EDGE and RED-E. 
Both EDGE (eq. 1) and RED-E (eq. 2) have two components: the ED component (e.g., $\ln (1+\mathrm{ED})$ in eq. 1) and the endangerment component (e.g., GE * $\ln (2)$ in eq.1). By keeping track of both component values for both EDGE and RED-E, I was able to examine the relative influence of RED, compared to RE, on the RED-E scores and how different they are from EDGE scores. I compared the difference between the number of standard deviations away from the mean of both RED-E and EDGE to the difference between the number of standard deviations away from the mean of global and regional endangerment and global and regional ED. I compared the $\mathrm{R}^{2}$ values of the change from global to regional endangerment and the change from global to regional ED to find which has the strongest correlation with the change from RED-E to EDGE.

Sensitivity to Values used for Threatened and Endangered Status

Regional endangerment, determined by the ESA's categories of 'threatened' or 'endangered' were set to a numerical value of 2 and 4, respectively for the calculation of the RED-E score. Those values were chosen to align most closely with the EDGE values used for the IUCN rankings, and to make the EDGE and RED-E ranking comparable. I explored the option of changing the values for the ESA categories to a 0 and 1 value and a 1 and 2 value by creating three different ranked lists using the three different value options (2 and 4, 0 and 1,1 and 2). The lists were compared and change in rank was calculated. 


\section{Cost of Protection}

To quantify previous ‘conservation attention,' I used the FWS’s conservation expenditure reports from 2001 to 2012, which detail the amount spent on the conservation of each ESA-listed species. I found the combined amount spent on "land" and "all but land" on the conservation of each species or population listed, and then regressed money spent against the RED-E value to find if species with high evolutionary diversity and peril levels have had more money spent on them.

\section{CH Priority}

I ranked those species that do not have critical habitat designated to them on the basis of RED-E scores, and compared them with EDGE scores to show the difference in rank between global and regional measures by regressing RED-E scores against EDGE scores. The ranked list can serve as a recommendation for which species should be prioritized for the designation of critical habitat in the future, given current listing status and (regional) evolutionary distinctiveness. 


\section{RESULTS}

RED-E

Regional evolutionary distinctiveness and endangerment (RED-E) scores for ESA- listed mammals range from 3.33 for the West Indian Manatee (Trichechus manatus) to 7.41 for the Utah Prairie Dog (Cynomys parvidens). The RED-E scores are approximately normally distributed, have a median of 5.33, and a mean of 5.30 . Evolutionary distinctiveness (using the global species pool) and global endangerment (EDGE) scores for ESA-listed mammals range from 0.55 in seven populations of Beach Mouse (Peromyscus polionotus) to 5.24 in the Blue Whale (Balaenoptera musculus). The EDGE scores are approximately normally distributed, have a median of 2.75, and a mean of 2.77. RED-E scores for ESA-listed mammals are positively correlated with their EDGE scores $\left(\mathrm{R}^{2}=0.10, \mathrm{p}\right.$-value $=0.0029$, Figure 2$)$ but result in very different rankings (Appendix B.1). On average, the RED-E score of mammals shifted by 0.98 deviations away from the mean, relative to its EDGE score. The shift in scores represented a change in the ranking by an average of 24 places.

For ESA-listed birds, RED-E scores range from 3.13 in the Roseate Tern (Sterna dougallii dougallii) to 6.26 in the Ivory-Billed Woodpecker (Campephilus principalis), respectively. The RED-E scores are approximately normally distributed, have a median of 5.10, and a mean of 5.01. The EDGE scores ranged from 1.76 for the Inyo California Towhee (Pipilo crissalis eremophilus) to 5.59 for the California Condor (Gymnogyps californianus). The EDGE scores are approximately normally distributed, have a median of 2.47, and a mean of 2.80. The RED-E scores for ESA-listed birds are not correlated with their EDGE scores $\left(\mathrm{R}^{2}=0.02\right.$, p-value $=0.33$, Figure 3, Appendix B.2). The RED- 
E score of birds shifted by an average of 1.08 deviations away from the mean, relative to its EDGE score. This shift represented a change in the ranking by an average of 13 places.

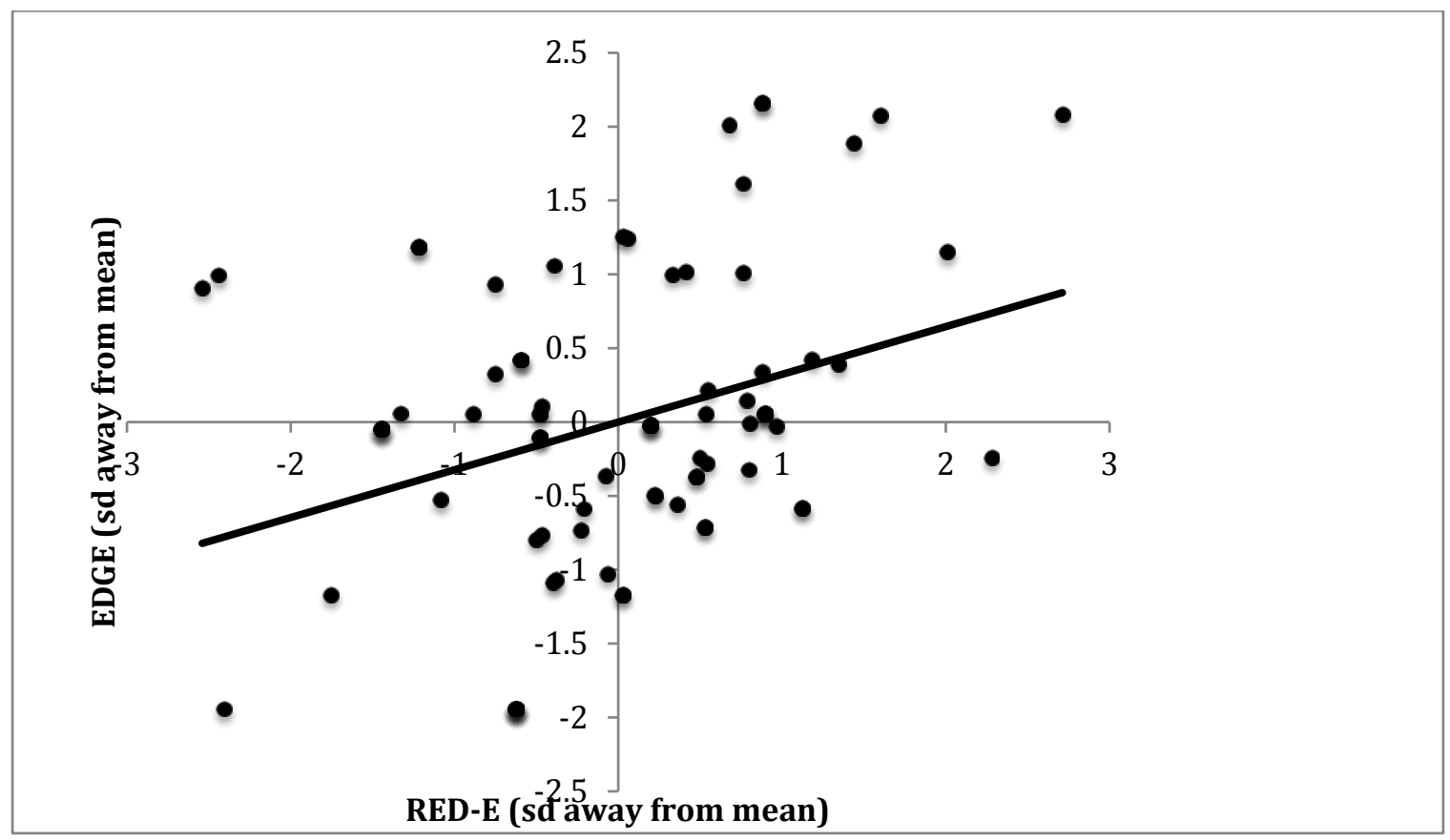

Figure 2. REGIONAL EVOLUTIONARY DISTINCTIVENESS AND ENDANGERMENT VERSUS GLOBAL EVOLUTIONARY DISTINCTIVENESS AND ENDANGERMENT IN MAMMALS: Correlation of standardized mammal RED-E and EDGE scores. $\mathrm{R}^{2}=0.10$. 


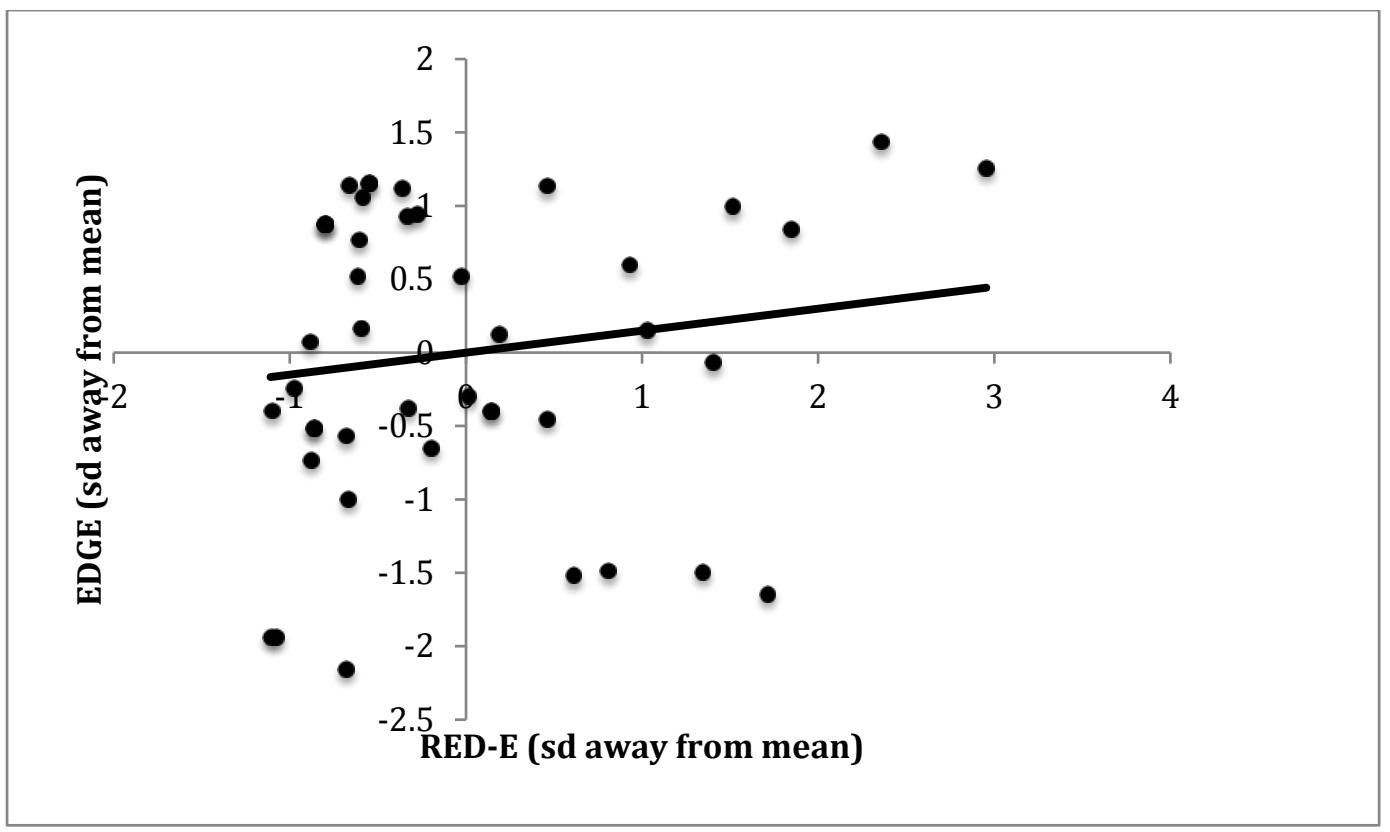

Figure 3. REGIONAL EVOLUTIONARY DISTINCTIVENESS AND ENDANGERMENT VERSUS GLOBAL EVOLUTIONARY DISTINCTIVENESS AND ENDANGERMENT IN BIRDS:

Correlation of standardized bird RED-E and EDGE scores. $\mathrm{R}^{2}=0.022$.

The difference in a species’ RED-E and EDGE scores, in terms of deviations away from the mean, is explained more by the change from global (IUCN) to local (ESA) endangerment listings, than by the change in ED values. The explanation is true for both mammals (mammals $\mathrm{R}^{2}=0.83>\mathrm{R}^{2}=0.23$, Figure 4) and birds $\left(\mathrm{R}^{2}=0.86>\mathrm{R}^{2}=0.17\right.$, Figure 5). 


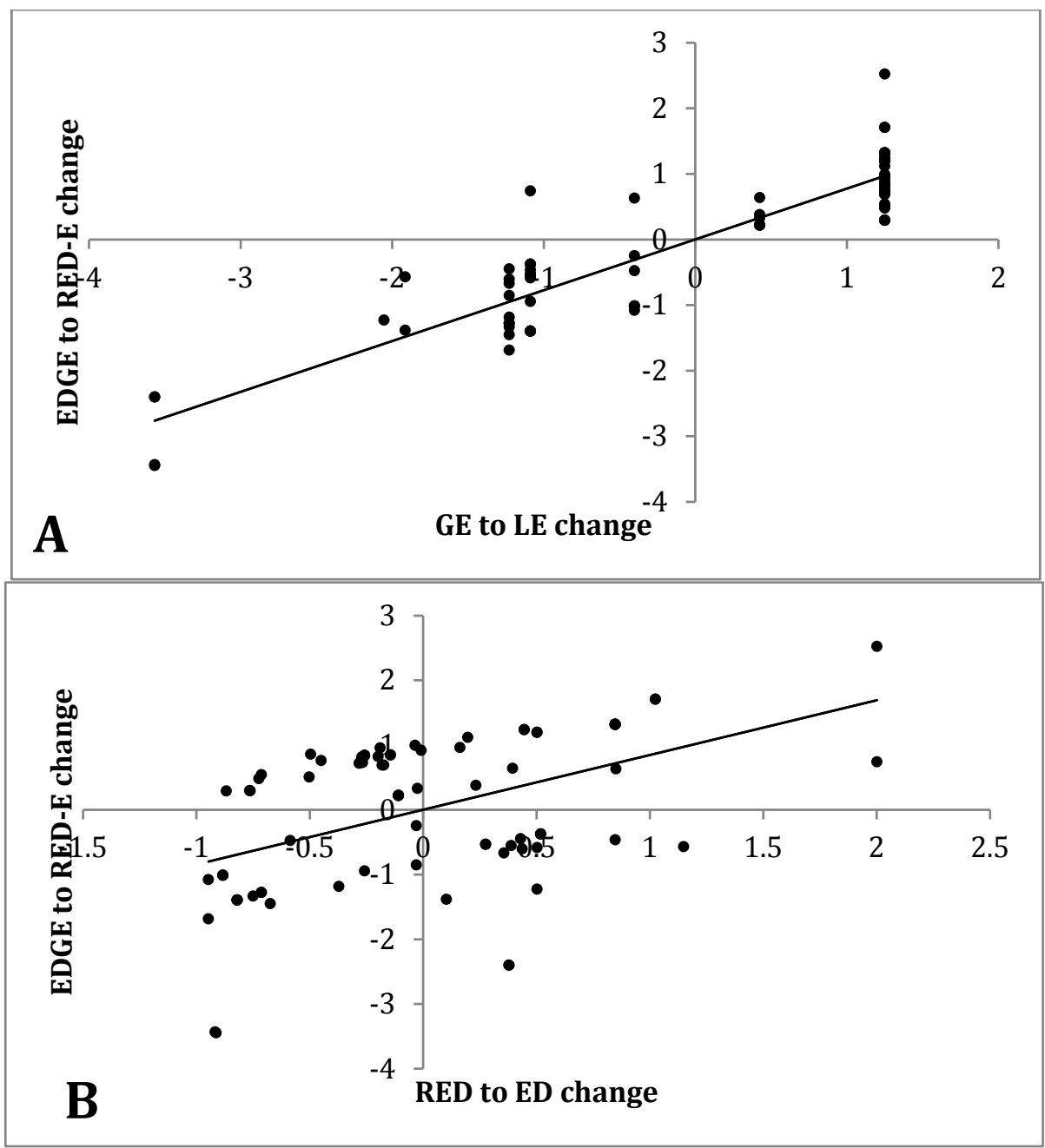

Figure 4: GLOBAL TO REGIONAL ENDANGERMENT AND GLOBAL TO REGIONAL EVOLUTIONARY DISTINCTIVENESS IMPACT (MAMMALS): A) The difference between mammal RED-E and EDGE correlated with the change from global to local endangerment. $\mathrm{R}^{2}=$ 0.83. B) The difference between mammal RED-E and EDGE correlated with the change from global to regional evolutionary distinctiveness. $\mathrm{R}^{2}=0.23$ 


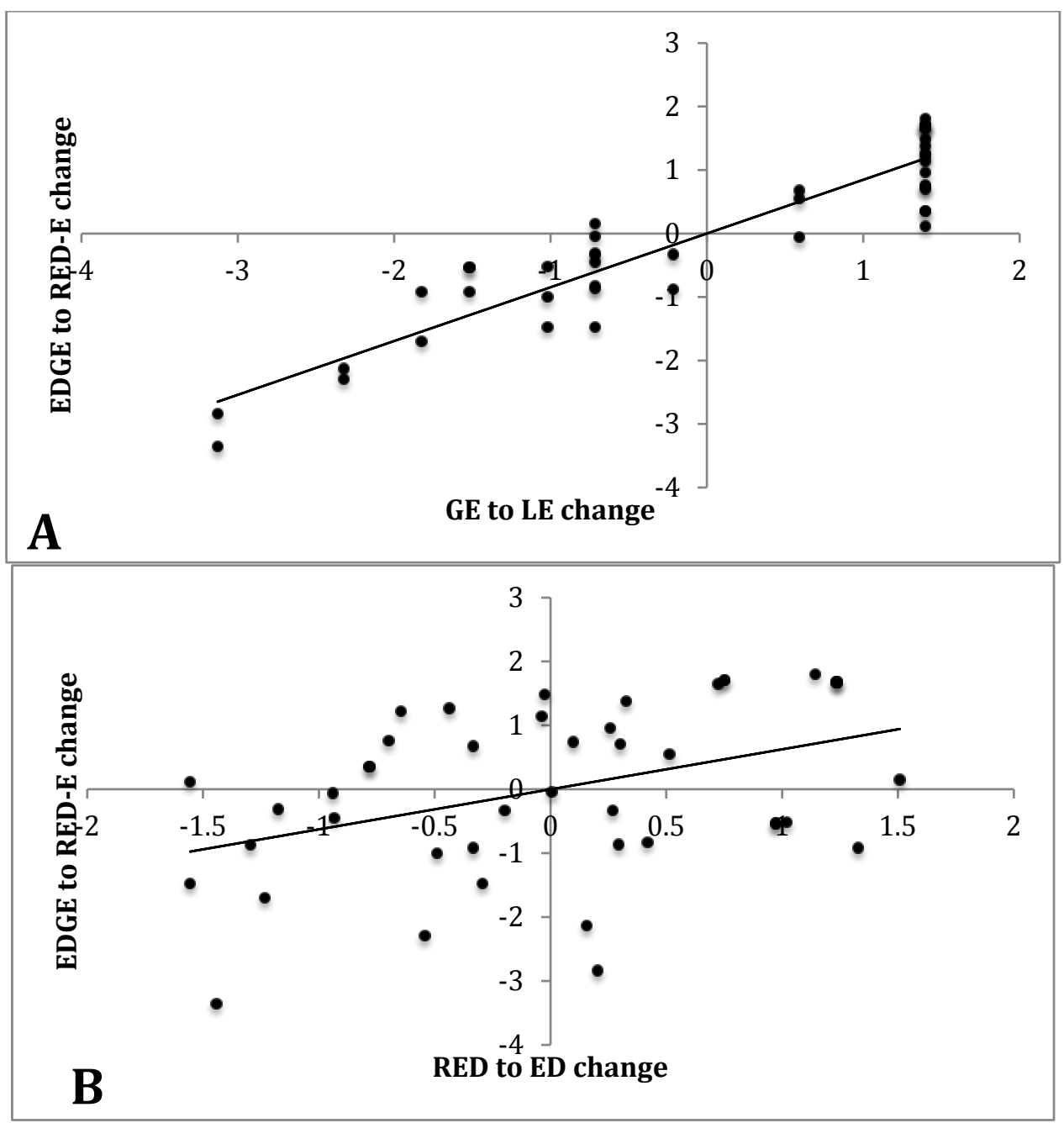

Figure 4: GLOBAL TO REGIONAL ENDANGERMENT AND GLOBAL TO REGIONAL EVOLUTIONARY DISTINCTIVENESS IMPACT (BIRDS): A) The difference between bird RED$E$ and EDGE correlated with the change from global to local endangerment. $R^{2}=0.86$. B) The difference between bird RED-E and EDGE correlated with the change from global to regional evolutionary distinctiveness. $\mathrm{R}^{2}=0.17$.

Sensitivity to values used for Threatened and Endangered status

The numerical value used for 'threatened' and ‘endangered' status had minimal effect on the ranking. The RED-E rank showed no difference between $\mathrm{T}=0, \mathrm{E}=1$ and $\mathrm{T}$ $=1, \mathrm{E}=2$. When changing from the RED-E standard $\mathrm{T}=2, \mathrm{E}=4$ to either of the other two, the rank did not change on the extreme ends in mammals or birds. The top 5 and 
bottom 4 priority species remained the same with all chosen values. Mammals showed one big change of 23 places, putting the first species listed as threatened in the top 30 priority species. Overall, threatened species prioritization increased when the values were changed to $\mathrm{T}=0, \mathrm{E}=1$ or $\mathrm{T}=1, \mathrm{E}=2$ (Appendix C.1, C.2).

\section{Cost of Protection}

There is no correlation between RED-E value and money spent on each species between 2001 and 2012 in mammals $(p=0.306)$ or birds $(p=0.598$; Figures 6, 7). Seven mammal species had a total cost of over $\$ 50$ million, and of those species, 4 were over $\$ 100$ million. The two mammal species with the highest cost are Ursus americanus luteolus (Louisiana Black Bear; \$178 million) and Eumetopias jubatus (Stellar Sea Lion; \$164 million). They are RED-E ranked 54th and 24th, respectively, and both have designated $\mathrm{CH}$. There are ten bird species with a cost of over $\$ 50$ million, and of those, six were over $\$ 100$ million. The two bird species with the highest costs, Picoides borealis (Red-Cockaded Woodpecker; \$302 million) and Mycteria americana (Wood Stork; \$280 million), are RED-E ranked 17th and 27th out of the 44 total species, and both have $\mathrm{CH}$ designated. 


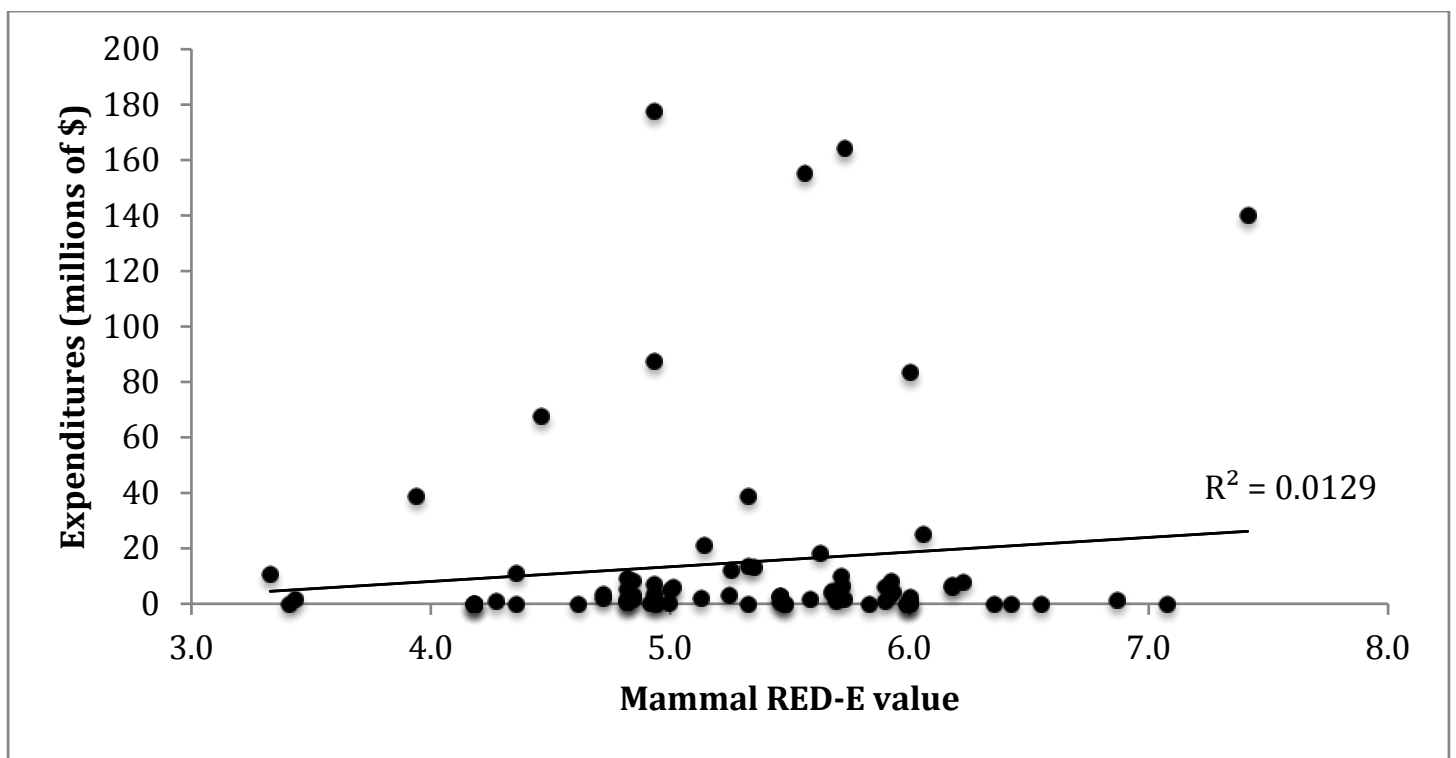

Figure 6. MAMMAL PREVIOUS COSTS: The amount of money spent on each mammal species from 2001 to 2012 against the calculated RED-E value. $\mathrm{R}^{2}=0.013$.

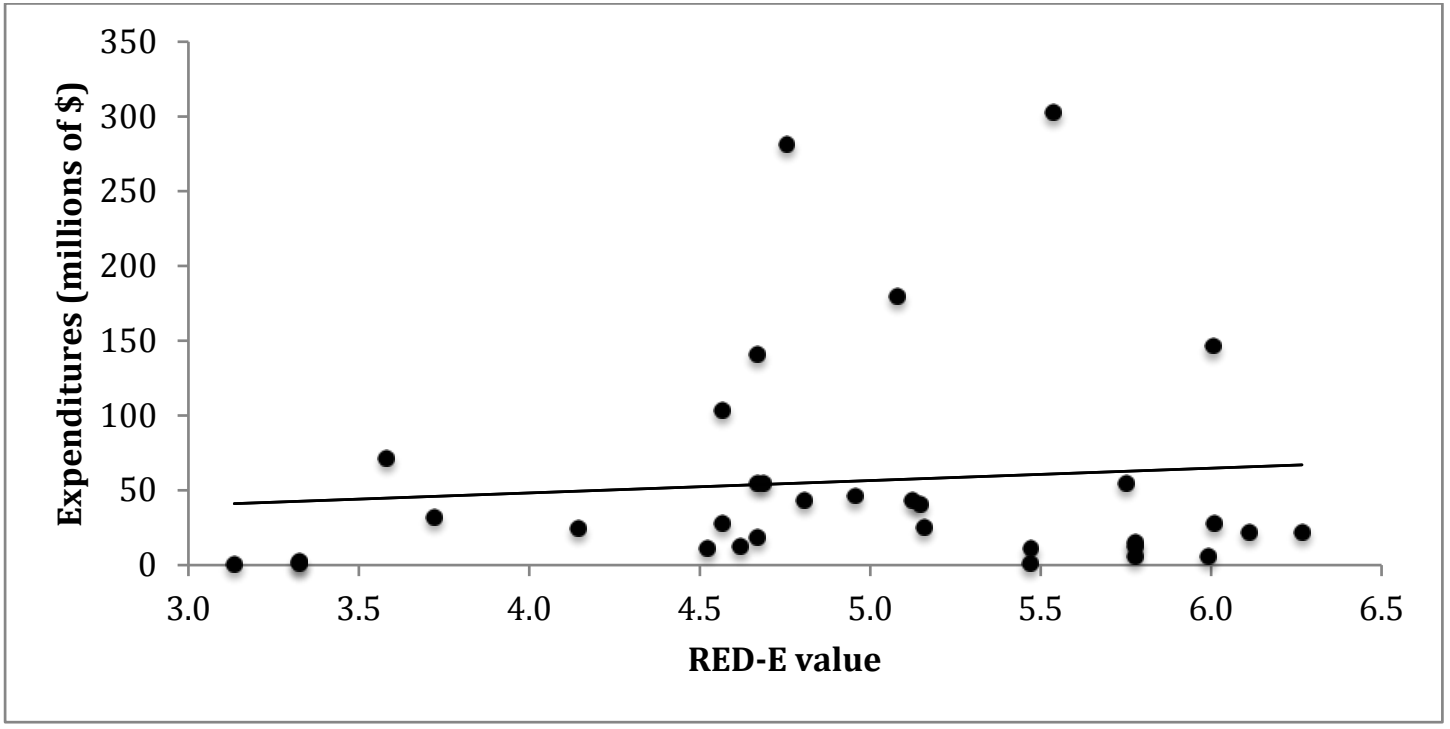

Figure 7. BIRD PREVIOUS COSTS: The amount of money spent on each bird species from 2001 to 2012 against the calculated RED-E value. $\mathrm{R}^{2}=0.0091$. 


\section{Critical Habitat}

In the ranking of species without critical habitat, RED-E and EDGE ranks are related in in mammals ( $p=0.0354$, F-statistic 4.694; Table 2), but unrelated in birds ( $p=0.246$, Fstatistic 1.41; Table 3). In mammals, rank changed by an average of 14 places. Bird rank changed by an average of 13 places.

Table 2: Recommended RED-E ranking for ESA mammal critical habitat designation. The EDGE rank of each species is presented, along with the difference between the RED-E and EDGE ranking.

\begin{tabular}{|c|c|c|c|}
\hline Mammals without $\mathrm{CH}$ & $\begin{array}{l}\text { RED-E } \\
\text { rank }\end{array}$ & $\begin{array}{l}\text { EDGE } \\
\text { rank }\end{array}$ & $\begin{array}{c}\text { EDGE to } \\
\text { RED-E } \\
\text { rank } \\
\text { change } \\
\end{array}$ \\
\hline $\begin{array}{r}\text { Aplodontia rufa nigra } \\
\text { Point Arena Mountain Beaver }\end{array}$ & 1 & 9 & +8 \\
\hline $\begin{array}{r}\text { Physeter catodon } \\
\text { Sperm Whale }\end{array}$ & 2 & 3 & +1 \\
\hline $\begin{array}{r}\text { Antilocapra americana sonoriensis } \\
\text { Sonoran Pronghorn }\end{array}$ & 3 & 18 & +15 \\
\hline $\begin{array}{r}\text { Brachylagus idahoensis } \\
\text { Pygmy Rabbit }\end{array}$ & 4 & 16 & +12 \\
\hline $\begin{array}{r}\text { Sylvilagus bachmani riparius } \\
\text { Riparian Brush Rabbit }\end{array}$ & 5 & 29 & +24 \\
\hline $\begin{array}{r}\text { Herpailurus yagouaroundi cacomitli } \\
\text { Gulf Coast Jaguarundi }\end{array}$ & 6 & 22 & +16 \\
\hline $\begin{array}{r}\text { Herpailurus yagouaroundi tolteca } \\
\text { Sinaloan Jaguarundi }\end{array}$ & 6 & 22 & +16 \\
\hline $\begin{array}{r}\text { Puma concolor coryi } \\
\text { Florida Panther }\end{array}$ & 6 & 22 & +16 \\
\hline $\begin{array}{r}\text { Puma concolor couguar } \\
\text { Eastern Cougar }\end{array}$ & 6 & 22 & +16 \\
\hline $\begin{array}{r}\text { Balaenoptera musculus } \\
\text { Blue Whale }\end{array}$ & 10 & 1 & -9 \\
\hline $\begin{array}{r}\text { Balaenoptera physalus } \\
\text { Finback Whale }\end{array}$ & 10 & 1 & -9 \\
\hline Megaptera novaeangliae & 12 & 19 & +7 \\
\hline
\end{tabular}


Humpback Whale Leopardus pardalis

Ocelot

Leptonycteris nivalis

Mexican Long-Nosed Bat

Leptonycteris curasoae yerbabuenae

Lesser Long-Nosed Bat

Balaenoptera borealis

Sei Whale

Glaucomys sabrinus coloratus

Carolina Northern Flying Squirrel

Neotoma fuscipes riparia

Riparian Woodrat

Odocoileus virginianus clavium

Key Deer

Odocoileus virginianus leucurus

Columbian White-Tailed Deer

Corynorhinus townsendii ingens

Ozark Big-Eared Bat

Mustela nigripes

Black-Footed Ferret

Sylvilagus palustris hefneri

Lower Keys Marsh Harvest Mouse

Lasiurus cinereus semotus

Hawaiian Hoary Bat

Reithrodontomys raviventris

Salt Marsh Harvest Mouse

Canis rufus

Red Wolf

Canis lupus baileyi

Mexican Gray Wolf

Sciurus niger cinereus

Delmarva Peninsula Fox Squirrel

Perognathus longimembris pacificus

Pacific Pocket Mouse

Myotis grisescens

Gray Bat

Neotoma floridana smalli

Key Largo Woodrat

Dipodomys ingens

Giant Kangaroo Rat

Microtus mexicanus hualpaiensis

13

34

$+21$

14

15

16

17

18

19

19

21

22

23

24

25

26

27

28

29

30

31

32

33
5

12

$-3$

$-12$

$+16$

33

27

$+9$

40

$+21$

$+21$

40

+

$36+15$

11

$-11$

$38+15$

$37+13$

7

$-18$

$-20$

$46+19$

$43+15$

35

$+6$

39

$+9$

44

$+13$

10

$-22$

45

$+12$ 


\begin{tabular}{|c|c|c|c|}
\hline \multicolumn{4}{|l|}{ Hualapai Mexican Vole } \\
\hline $\begin{array}{r}\text { Bison bison athabascae } \\
\text { Wood Bison }\end{array}$ & 34 & 20 & -14 \\
\hline $\begin{array}{r}\text { Ursus americanus } \\
\text { American Black Bear }\end{array}$ & 35 & 28 & -7 \\
\hline $\begin{array}{r}\text { Ursus arctos horribilis } \\
\text { Grizzly Bear }\end{array}$ & 36 & 30 & -6 \\
\hline $\begin{array}{r}\text { Ursus arctos horribilis } \\
\text { Grizzly Bear }\end{array}$ & 36 & 30 & -6 \\
\hline $\begin{array}{r}\text { Ursus arctos horribilis } \\
\text { Grizzly Bear }\end{array}$ & 36 & 30 & -6 \\
\hline $\begin{array}{r}\text { Microtus pennsylvanicus dukecampbelli } \\
\text { Florida Salt Marsh Vole }\end{array}$ & 39 & 42 & +3 \\
\hline $\begin{array}{r}\text { Dipodomys nitratoides nitratoides } \\
\text { Tipton Kangaroo Rat }\end{array}$ & 40 & 17 & -23 \\
\hline $\begin{array}{r}\text { Peromyscus gossypinus allapaticola } \\
\text { Key Largo Cotton Mouse }\end{array}$ & 41 & 47 & +6 \\
\hline $\begin{array}{l}\text { Peromyscus polionotus phasma } \\
\text { Anastasia Island Beach Mouse }\end{array}$ & 41 & 47 & +6 \\
\hline $\begin{array}{r}\text { Dipodomys stephensi } \\
\text { Stephens’ Kangaroo Rat }\end{array}$ & 43 & 14 & -29 \\
\hline $\begin{array}{r}\text { Puma concolor (all subsp. except coryi) } \\
\text { Mountain Lion }\end{array}$ & 44 & 22 & -22 \\
\hline $\begin{array}{r}\text { Enhydra lutris nereis } \\
\text { Southern Sea Otter }\end{array}$ & 45 & 8 & -37 \\
\hline $\begin{array}{r}\text { Arctocephalus townsendi } \\
\text { Guadalupe Fur Seal }\end{array}$ & 46 & 21 & -25 \\
\hline $\begin{array}{r}\text { Peromyscus polionotus niveiventris } \\
\text { Southeastern Beach Mouse }\end{array}$ & 47 & 49 & +2 \\
\hline $\begin{array}{l}\text { Spermophilus brunneus brunneus } \\
\text { Northern Idaho Ground Squirrel }\end{array}$ & 48 & 13 & -35 \\
\hline $\begin{array}{l}\text { Cynomys parvidens } \\
\text { Utah Prairie Dog }\end{array}$ & 49 & 15 & -34 \\
\hline
\end{tabular}


Table 3: Recommended RED-E ranking for ESA bird critical habitat designation. The EDGE rank of each species is presented, along with the difference between the RED-E and EDGE ranking.

\begin{tabular}{|c|c|c|c|}
\hline Birds without $\mathrm{CH}$ & $\begin{array}{l}\text { RED-E } \\
\text { rank }\end{array}$ & $\begin{array}{l}\text { EDGE } \\
\text { rank }\end{array}$ & $\begin{array}{c}\text { EDGE to } \\
\text { RED-E } \\
\text { rank } \\
\text { change }\end{array}$ \\
\hline $\begin{array}{l}\text { Campephilus principalis } \\
\text { Ivory-Billed Woodpecker }\end{array}$ & 1 & 1 & 0 \\
\hline $\begin{array}{l}\text { Gallinula chloropus guami } \\
\text { Mariana Common Moorhen }\end{array}$ & 2 & 13 & +11 \\
\hline $\begin{array}{l}\text { Gallinula chloropus sandvicensis } \\
\text { Hawaiian Common Moorhen }\end{array}$ & 2 & 13 & +11 \\
\hline $\begin{array}{r}\text { Himantopus mexicanus knudseni } \\
\text { Hawaiian Stilt }\end{array}$ & 4 & 15 & +11 \\
\hline $\begin{array}{r}\text { Rhynchopsitta pachyrhyncha } \\
\text { Thick-Billed Parrot }\end{array}$ & 5 & 2 & -3 \\
\hline $\begin{array}{r}\text { Buteo platypterus brunnescens } \\
\text { Puerto Rican Broad-Winged Hawk }\end{array}$ & 6 & 11 & +5 \\
\hline $\begin{array}{r}\text { Accipiter striatus venator } \\
\text { Puerto Rican Sharp-Shinned Hawk }\end{array}$ & 7 & 12 & +5 \\
\hline $\begin{array}{l}\text { Rallus longirostris levipes } \\
\text { Light-Footed Clapper Rail }\end{array}$ & 8 & 21 & +13 \\
\hline $\begin{array}{l}\text { Rallus longirostris obsoletus } \\
\text { California Clapper Rail }\end{array}$ & 8 & 21 & +13 \\
\hline $\begin{array}{r}\text { Rallus longirostris yumanensis } \\
\text { Yuma Clapper Rail }\end{array}$ & 8 & 21 & +13 \\
\hline $\begin{array}{r}\text { Fulica americana alai } \\
\text { Hawaiian Coot }\end{array}$ & 11 & 17 & +6 \\
\hline $\begin{array}{r}\text { Picoides borealis } \\
\text { Red-Cockaded Woodpecker }\end{array}$ & 12 & 5 & -7 \\
\hline $\begin{array}{l}\text { Falco femoralis septentrionalis } \\
\text { Northern Aplomado Falcon }\end{array}$ & 13 & 18 & +5 \\
\hline $\begin{array}{r}\text { Colinus virginianus ridgwayi } \\
\text { Masked Bobwhite }\end{array}$ & 14 & 9 & -5 \\
\hline $\begin{array}{r}\text { Lanius ludovicianus mearnsi } \\
\text { San Clemente Loggerhead Shrike }\end{array}$ & 15 & 16 & +1 \\
\hline
\end{tabular}




\begin{tabular}{|c|c|c|c|}
\hline $\begin{array}{r}\text { Vireo atricapilla } \\
\text { Black-Capped Vireo }\end{array}$ & 16 & 4 & -12 \\
\hline $\begin{array}{l}\text { Dendroica chrysoparia } \\
\text { Golden-Cheeked Warbler }\end{array}$ & 17 & 3 & -14 \\
\hline $\begin{array}{r}\text { Ammodramus savannarum floridanus } \\
\text { Florida Grasshopper Sparrow }\end{array}$ & 18 & 26 & +8 \\
\hline $\begin{array}{r}\text { Mycteria americana } \\
\text { Wood Stork }\end{array}$ & 19 & 8 & -11 \\
\hline $\begin{array}{r}\text { Sterna antillarum } \\
\text { Least Tern }\end{array}$ & 20 & 24 & +4 \\
\hline $\begin{array}{l}\text { Sterna antillarum browni } \\
\text { California Least Tern }\end{array}$ & 20 & 24 & +4 \\
\hline $\begin{array}{r}\text { Sterna dougallii dougallii } \\
\text { Roseate Tern }\end{array}$ & 22 & 19 & -3 \\
\hline $\begin{array}{r}\text { Calidris canutus rufa } \\
\text { Red Knot }\end{array}$ & 23 & 10 & -13 \\
\hline $\begin{array}{r}\text { Aphelocoma coerulescens } \\
\text { Florida Scrub-Jay }\end{array}$ & 24 & 6 & -18 \\
\hline $\begin{array}{l}\text { Tympanuchus pallidicinctus } \\
\text { Lesser Prairie-Chicken }\end{array}$ & 25 & 7 & -18 \\
\hline $\begin{array}{l}\text { Amphispiza belli clementeae } \\
\text { San Clemente Sage Sparrow }\end{array}$ & 26 & 27 & +1 \\
\hline $\begin{array}{r}\text { Sterna dougallii dougallii } \\
\text { Roseate Tern }\end{array}$ & 27 & 20 & -7 \\
\hline
\end{tabular}




\section{DISCUSSION}

\section{RED-E versus EDGE}

Regional evolutionary distinctiveness and endangerment (RED-E) is the regional version of the global evolutionary distinctiveness and endangerment (EDGE) approach to species conservation prioritization. Both RED-E and EDGE can look at the same species or populations of species, but are calculated for different geographies. The RED-E approach makes the global issue of biodiversity loss more relevant for a given country’s or region's priorities than the EDGE approach. Many governments, the US included, create their own list of endangerment separate from the IUCN for species within their borders, and have a specific country-oriented mindset of protecting those species. The IUCN is the gold standard of endangerment listing for species (Rodrigues et al. 2006). The IUCN has been rigorously researched, the categories are accurate at a global level, and it is constantly updated, but it does not go into details of subspecies or specific geographic populations (Rodrigues et al. 2006). Unfortunately, in the case of the U.S.A., the lines separating a "threatened” versus “endangered” species are not always clear, but the listing is still a valuable tool to assess regional rather than global endangerment rates (Tear et al. 1995).

While the political boundaries of a specific country do not necessarily correlate with any biophysical boundaries, they do correspond to each country’s jurisdiction and conservation policies. If we can provide individual countries with the tools to protect their own species, then the big-picture problem of biodiversity loss is made more manageable by a multitude of small-scale efforts. Within the US, the Endangered Species Act (ESA) only ranks species by one of two classifications: threatened or 
endangered. Of the 1577 species listed by the ESA, the ESA mainly rely on political or public pressure to decide which species on which they should focus conservation efforts (Metrick \& Weitzman 1998). The rankings created by RED-E would allow a government or group to target the species most endangered and most genetically unique in their specific area. I expected to find a greater correlation between RED-E and EDGE, but the analyses showed only a slight correlation in mammals and no correlation in the bird rankings. The difference between the RED-E and EDGE score was more affected by the change in endangerment status, from ESA to IUCN, than by the regional or global evolutionary distinctiveness (ED). Since there are only two listing categories in the ESA, as opposed to the four categories of the IUCN, I expected a fairly large change between the two.

The many benefits of evolutionary distinctiveness and global endangerment (EDGE) are discussed at length in Isaac et al. (2007): it is simple to use, indicative of biodiversity, and fairly robust to uncertainty. Many of those same benefits apply to REDE as well. All that is required to calculate RED-E is a region-specific assessment level and a complete or almost complete phylogenetic tree with at least 100 species (Isaac et al. 2007). Furthermore, although the mammal and bird trees were analyzed separately, they could be combined into a master rank list based on their RED-E scores. As long as all phylogenetic trees used have at least 100 species and no overlapping species occur across trees, the RED-E scores can be compared directly.

One major benefit of RED-E over EDGE is that it may help to save individual populations that could play a large role in individual ecosystems, such as keystone predators. For example, Puma concolor is listed by the IUCN as Least Concern, but in 
the Florida Everglades, Puma concolor coryi, or the Florida Panther, have previously been critically endangered, though their population is currently increasing (FWC 3013). By EDGE standards, the Florida Panther was ranked $31^{\text {st }}$ by the ESA priority list, but by RED-E standards, which take individual populations into account, they were ranked $11^{\text {th }}$. Florida panthers are keystone predators that fill an important ecological niche. If they disappear, there could be cascading effects that may endanger other species as well (Mills et al. 1993). One of the benefits of using ED in rank calculations in general is that genetically distinct species often have unique roles in an ecosystem that will not be easily taken over by closely related species (Winter et al. 2012). In a resource-limited conservation plan, choosing the species that are most unique will preserve the most branches in the phylogenetic tree of life. The current selective species loss, or loss of many species from the same lineage, drops whole branches of the tree, and all of the information contained in that genetic code is lost forever (McKinney 1998, Purvis et al. 2000). If we can prioritize and save even one species within each clade, we can preserve much of the current genetic diversity found on Earth.

Sensitivity to values used for Threatened and Endangered status

The 'threatened' and 'endangered' values of 2 and 4 were chosen because they most closely align with the 0-4 IUCN values used by the EDGE approach. Within the IUCN, 'critically endangered' is valued at 4 and 'vulnerable' is valued at 2. Although those matched up well, I wanted to test for the impact that the values actually had on the RED-E outcome. The other values tested $(T=0, E=1$ and $T=1, E=2)$, significantly reduced the impact of the regional endangerment component of the RED-E value, and 
therefore would break down some of the prioritization that is already in place based on the current 'threatened' and 'endangered' statuses. Only with extremely genetically distinct species should a threatened species be prioritized over an endangered species.

\section{Cost of protection}

The amount spent on each ESA-listed species is published by the FWS every year. These numbers can be used as indicators of past conservation attention. I found no relationship between RED-E and funding. This was surprising because the RED-E score is very sensitive to the ESA status, and 'endangered' species are more likely to have dedicated recovery plans than 'threatened' species (Taylor et al. 2005). Because the only categories that the ESA uses are 'endangered' and 'threatened,' I expected to see more money spent on endangered species, and expected RED-E’s valuing of endangered species to show that.

Unsurprisingly, the seven mammals with the most past conservation attention (greater than \$50 million spent) are mostly large, charismatic species. Except for one species of bat, they are all big cats (Ocelot and the Florida Panther), bears (two populations of Black Bears), or large aquatic mammals (Sea Lions and Manatees). Only four of the seven were listed as endangered by the ESA, which was unexpected. If species listed as “endangered” are more at risk of extinction than species listed as “threatened," we would expect to see greater efforts being made toward the endangered species. 


\section{Critical Habitat}

As a practical application for governmental RED-E use, I created a ranked list of species that do not currently have critical habitat $(\mathrm{CH})$ designation. As all species should legally have $\mathrm{CH}$ designated, the $\mathrm{CH}$ priority list could be put into effect immediately. While there is some debate over whether $\mathrm{CH}$ is truly effective, any positive effect toward endangered species, specifically, should be prioritized. Critical habitat designation does improve the status of listed species by encouraging people to modify land-use and increasing public education in those areas (Hagen \& Hodges 2005). Critical habitat is also the only protection in the ESA for unoccupied habitat, and species that have the designation are more likely to recovery plans that are actively implemented and revised (Hagen \& Hodges 2005). Species listed as ‘endangered’ show less recovery over time than 'threatened' species. More ‘endangered’ species have dedicated recovery plans by the ESA than 'threatened' species, but the proportions of $\mathrm{CH}$ designations are roughly the same. Increasing $\mathrm{CH}$ habitat designation in endangered species may help to increase the recovery of species listed as ‘endangered’ (Taylor et al. 2005). As RED-E fairly heavily favors endangered species over threatened species, it is an appropriate approach to the lack of $\mathrm{CH}$ for ESA-listed species.

\section{Limitations and future study}

One limitation to both the RED-E and the EDGE method is that closely related species that are all endangered may be moved lower on the priority list. Because of the way RED-E is calculated (the regional ED component added to the regional endangerment component), regional ED can only have so much effect on the overall 
RED-E score. As long as a species is endangered, it should still be fairly high on the list. Although the endangerment level should help to balance that out, care should still be taken when looking at a ranked list. No prioritization method can pull in all possible variables. The use of RED-E is an attempt at an easy, one number system for governments and organizations.

Unfortunately, current, dated, and accurate phylogenetic trees are not always readily available, especially for species such as invertebrates, which are less charismatic than vertebrates. Without the existence of a nearly-complete phylogenetic tree, neither RED-E nor EDGE will present an accurate priority list.

Furthermore, the nearly-complete phylogenetic trees we do have are not $100 \%$ accurate. Fortunately, most of those inaccuracies come from branches far from the terminal branches, and most of the ED comes from the last few branches left on the tree. As more genetic analysis is done, though, species are being shifted around from genus to genus, which would affect the ED component of the RED-E value.

\section{Recommendations}

The RED-E approach should be simple to use for all governmental or conservation agencies. The recommended steps to creating a RED-E ranked priority list are as follows:

1. Identify area for conservation planning, all species being considered there, and all species of concern there (species there must total over 100). 
2. Collect phylogenetic trees for global clade chosen. Multiple trees can be used for the same ranked list as long as each tree has more than 100 species and no overlapping species.

3. Trim trees to only the species in the chosen area using the guideline R-code in supplementary material.

4. Use R, caper, and the ed.calc function to calculate regional evolutionary diversity for each species.

5. Use agency conservation status and assign number values, preferably from 0-4 that match up with the IUCN status, to each species. If no agency conservation status is available, the IUCN status can be used.

6. Calculate the regional evolutionary distinctiveness (RED) component

$$
R E D \text { component }=\ln (1+R E D)
$$

7. Calculate the regional endangerment (RE) component

$$
R E \text { component }=\mathrm{R} E * \ln (2)
$$

8. Add RED and RE together to find the RED-E score.

9. Order the RED-E scores from largest to smallest to create the final ranked list, with the largest number as the species of most concern. Consider all scores that are ties as equal in rank.

The created RED-E list is a fairly simple ranking system used to make decisions about where limited resources may be best spent in conservation strategies. While it is simple, it could be a powerful tool for organizing conservation efforts. Hopefully, with this and the concerted effort of governments and agencies around the world, we can make a move toward mitigating biodiversity loss. 


\section{REFERENCES}

American Society of Mammologists (ASM). (2015). State-specific lists of indigenous mammals. http://www.mammalsociety.org/mammals-list (visited April 15, 2015)

Arponen, A. (2012). Prioritizing species for conservation planning. Biodivers. Conserv. 21, 875-893.

Bininda-Emonds, O. R., Cardillo, M., Jones, K. E., MacPhee, R. D., Beck, R. M., Grenyer, R., ... \& Purvis, A. (2007). The delayed rise of present-day mammals. Nature, 446(7135), 507-512.

Bennett, P. M., \& Owens, I. P. (1997). Variation in extinction risk among birds: chance or evolutionary predisposition?. Proceedings of the Royal Society of London. Series B: Biological Sciences, 264(1380), 401-408.

Brook, B. W., Sodhi, N. S., \& Bradshaw, C. J. (2008). Synergies among extinction drivers under global change. Trends in ecology \& evolution, 23(8), 453-460.

Butchart SHM, Walpole M, Collen B, van Strien A, Scharlemann JPW, et al. (2010) Global biodiversity: indicators of recent declines. Science 328: $1164\{1168$.

Cadotte, M. W., Dinnage, R., \& Tilman, D. (2012). Phylogenetic diversity promotes ecosystem stability. Ecology, 93(sp8), S223-S233.

Cardoza, J. E., \& Langlois, S. A. (2002). The eastern cougar: a management failure?. Wildlife Society Bulletin, 265-273.

Clark, T. W. 1992. Practicing natural resource management with a policy orientation. Environmental Management 16:423- 433.

Cowlishaw, G. (1999). Predicting the pattern of decline of African primate diversity: an extinction debt from historical deforestation. Conservation Biology, 13(5), 11831193.

Department of the Interior, U.S. Fish and Wildlife Services (FWS). (1973). Endangered Species Act of 1973. Washington, D.C. 20240.

Department of the Interior, U.S. Fish and Wildlife Sevices (FWS). (2015a). Endangered Species. http://www.fws.gov/endangered/

Department of the Interior, U.S. Fish and Wildlife Sevices (FWS). (2015b). Northeast Region: Eastern Cougar. http://www.fws.gov/northeast/ECougar/newsrelease final.html 
Faith, D. P. (1992). Conservation evaluation and phylogenetic diversity. Biological conservation, 61(1), 1-10.

FWC (2013) Annual report on the research and management of Florida panthers: 20102013. Fish and Wildlife Research Institute and Division of Habitat and Species Conservation, Florida Fish and Wildlife Conservation Commission, Naples, FL, USA.

Grelle, C. E. D. V., Fonseca, G. A. B., Fonseca, M. T., \& Costa, L. P. (1999). The question of scale in threat analysis: a case study with Brazilian mammals. Animal Conservation, 2(2), 149-152.

Hagen, A. N., \& Hodges, K. E. (2006). Resolving critical habitat designation failures: reconciling law, policy, and biology. Conservation Biology, 20(2), 399-407.

Isaac NJB, Redding DW, Meredith HM, Sa_K (2012) Phylogenetically-informed priorities for amphibian conservation. PLoS ONE 7: e43912

Isaac NJB, Turvey ST, Collen B, Waterman C, Baillie JEM (2007) Mammals on the EDGE:conservation priorities based on threat and phylogeny. PLoS ONE 2: e296

International Union for the Conservation of Nature (IUCN). (2014) IUCN Red List of threatened species. Version 2014.3. World Conservation Union, Gland, Switzerland and Cambridge , UK . URL http://www.iucnredlist.org (visited April 15, 2015).

Jetz, W., Thomas, G. H., Joy, J. B., Hartmann, K., \& Mooers, A. O. (2012). The global diversity of birds in space and time. Nature, 491(7424), 444-448.

Jetz W, Thomas GH, Joy JB, Redding DW, Hartmann K, et al. (2014) Global distribution and conservation of evolutionary distinctness in birds. Current Biology 24: $919\{930$.

Mace, G. M. \& Balmford, A. (1999). Future Priorities for the Conservation of Mammalian Diversity (eds Entwhistle, A. \& Dunstone, N.). Cambridge Univ. Press, Cambridge.

May, R. M., Lawton, J. H., \& Stork, N. E. (1995). Assessing extinction rates. Extinction rates, 1-24.

Metrick, A., \& Weitzman, M. L. (1998). Conflicts and choices in biodiversity preservation. The Journal of Economic Perspectives, 21-34. 
McKinney, M. L. (1997). Extinction vulnerability and selectivity: combining ecological and paleontological views. Annual Review of Ecology and Systematics, 495-516.

McKinney, M. L. (1998). Branching models predict loss of many bird and mammal orders within centuries. Animal Conservation, 1(3), 159-164.

Millennium Ecosystem Assessment (2005) Ecosystems and human well-being: synthesis. Island Press, Washington, DC.

Mills, L. S., Soulé, M. E., \& Doak, D. F. (1993). The keystone-species concept in ecology and conservation. BioScience, 219-224.

Mouquet, N. Devictor, V., Meynard, C. N., Munoz, F., Bersier, L. F., Chave, J., ... \& Thuiller, W. (2012). Ecophylogenetics: advances and perspectives. Biological Review. 87, 769-785

Near, T. J., Eytan, R. I., Dornburg, A., Kuhn, K. L., Moore, J. A., Davis, M. P., ... \& Smith, W. L. (2012). Resolution of ray-finned fish phylogeny and timing of diversification. Proceedings of the National Academy of Sciences, 109(34), 13698-13703.

Nee, S., \& May, R. M. (1997). Extinction and the loss of evolutionary history. Science, 278(5338), 692-694.

Nelson, E. J., Withey, J. C., Pennington, D., \& Lawler, J. J. (2015). Identifying the Impacts of Critical Habitat Designation on Land Cover Change (No. dp-15-27).

Orme, D. (2013). The caper package: comparative analysis of phylogenetics and evolution in R. $R$ package version, 5(2).

Pearse, W. D., M. W. Chase, M. J. Crawley, K. Dolphin, M. F. Fay, J. A. Joseph, G. Powney, C. D. Preston, G. Rapacciuolo, D. B. Roy, and A. Purvis. (2014). On the EDGE with EDAM: prioritizing British plant species according to evolutionary distinctiveness, and accuracy and magnitude of decline. PLoS ONE. PONE-D-14-17956R2.

Pimm, S. L. (1998). Extinction. Conservation science and action, 20-38.

Polasky, S., Csuti, B., Vossler, C. A., \& Meyers, S. M. (2001). A comparison of taxonomic distinctness versus richness as criteria for setting conservation priorities for North American birds. Biological Conservation, 97(1), 99-105.

Purvis, A., Agapow, P. M., Gittleman, J. L., \& Mace, G. M. (2000). Nonrandom extinction and the loss of evolutionary history. Science, 288(5464), 328-330. 
R Development Core Team, R Development Core Team (R), Team RDC (2013) R: A language and environment for statistical computing. Available:http://www.rproject.org.

Redding DW, Mooers A_ (2006) Incorporating evolutionary measures into conservation prioritization. Conservation Biology 20: $1670\{1678$.

Russell, G. J., Brooks, T. M., McKinney, M. M., \& Anderson, C. G. (1998). Present and future taxonomic selectivity in bird and mammal extinctions. Conservation Biology, 12(6), 1365-1376.

Smithsonian National Museum of Natural History. (2015). North American Mammals. http://www.mnh.si.edu/mna/ (visited April 15, 2015).

Suckling, K. F., \& Taylor, M. (2005). 7 Critical Habitat and Recovery. The Endangered Species Act at Thirty: Vol. 1: Renewing the Conservation Promise, 75.

Taylor, M. F., Suckling, K. F., \& Rachlinski, J. J. (2005). The effectiveness of the Endangered Species Act: a quantitative analysis. BioScience, 55(4), 360-367.

Tear, T. H., Scott, J. M., Hayward, P. H., \& Griffith, B. (1995). Recovery plans and the Endangered Species Act: Are criticisms supported by data?. Conservation Biology, 9(1), 182-195.

Vidal, N., \& Hedges, S. B. (2005). The phylogeny of squamate reptiles (lizards, snakes, and amphibians) inferred from nine nuclear protein-coding genes. Comptes rendus biologies, 328(10), 1000-1008.

Wake, D. B., \& Vredenburg, V. T. (2008). Are we in the midst of the sixth mass extinction? A view from the world of amphibians. Proceedings of the National Academy of Sciences, 105(Supplement 1), 11466-11473.

Weitzman ML (1998) The Noah's Ark problem. Econometrica 66: 1279-1298.

Wilson, D. E., Reeder, D. M. (2005). Mammal Species of the World. Johns Hopkins University Press, 2, 142 pp.

Wilson, E. O. (1992).The Diversity of Life. Norton, New York.

Winter, M., Devictor, V., \& Schweiger, O. (2013). Phylogenetic diversity and nature conservation: where are we?. Trends in ecology \& evolution, 28(4), 199-204.

World Institute for Conservation and Environment (WICE). (2015). Birds of the USA. Birdlist.org (visited May 2, 2015). 
Zanne, A. E., Tank, D. C., Cornwell, W. K., Eastman, J. M., Smith, S. A., FitzJohn, R. G., ... \& Beaulieu, J. M. (2014). Three keys to the radiation of angiosperms into freezing environments. Nature, 506(7486), 89-92. 


\section{APPENDIX}

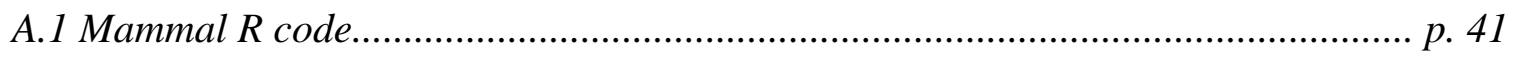

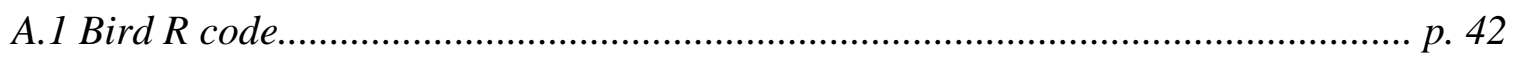

B.1 Full RED-E mammal calculation.............................................................. p. 44

B.2 Full RED-E bird calculation................................................................ p. 51

C.1 Sensitivity of mammal ranking to Threatened and Endangered values................ p. 55

C. 2 Sensitivity of bird ranking to Threatened and Endangered values..................... p. 62 


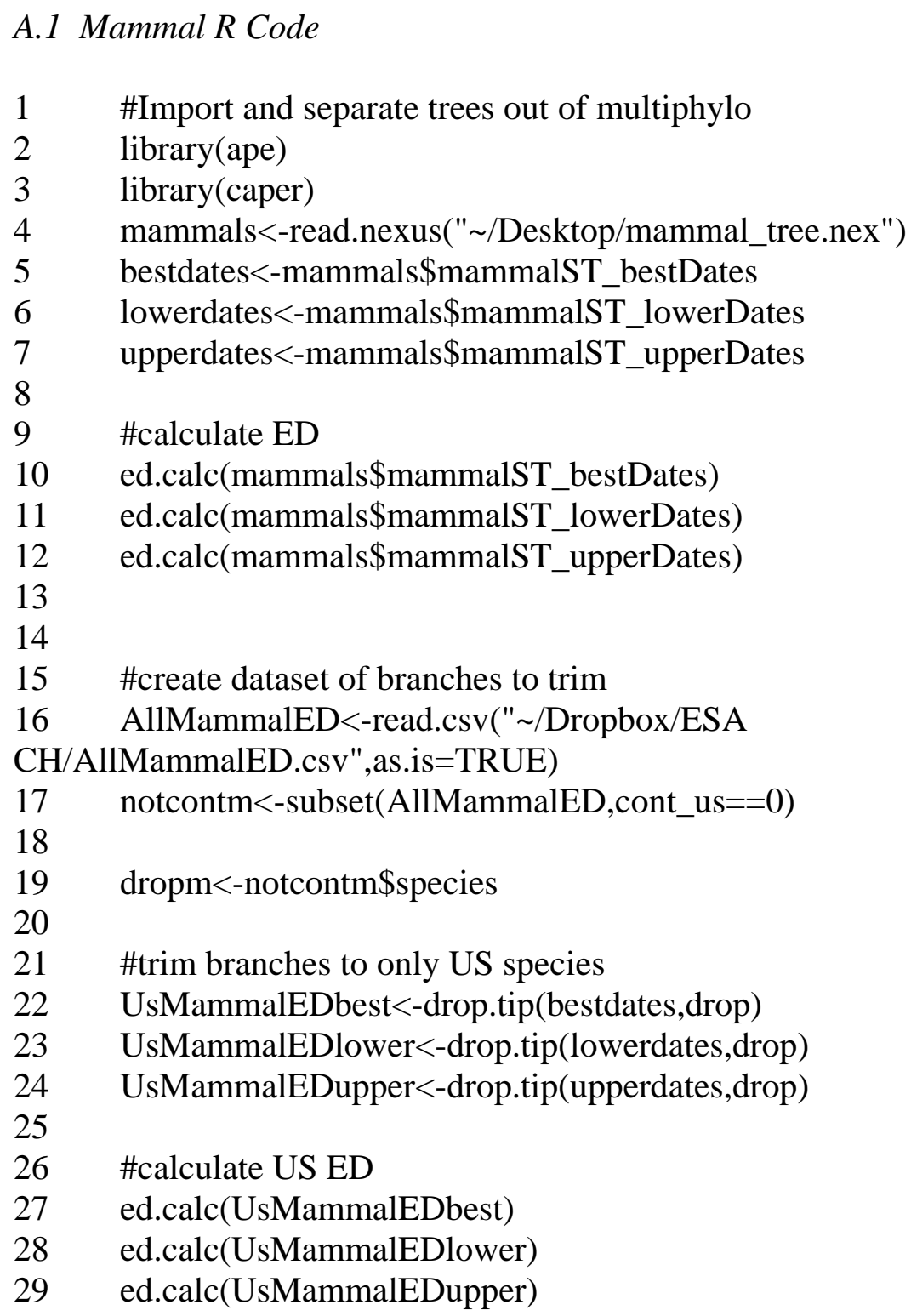




\section{A.2 Bird R Code}

1 library(ape)

2 library(caper)

3 birds<-read.tree(" /Dropbox/ESA CH/Bird/AllBirdsEricson1.tre")

4

$5 \quad$ \# loop for taking ED from 1000 bird trees

6

7 temp.list $<-$ NULL

8 temp.ed $<-$ NULL

9 spp.ed $<-$ NULL

10 output.ed<-NULL

11

12

\#loop for ED of 1000 trees

temp.list $<$-NULL

temp.ed<-NULL 


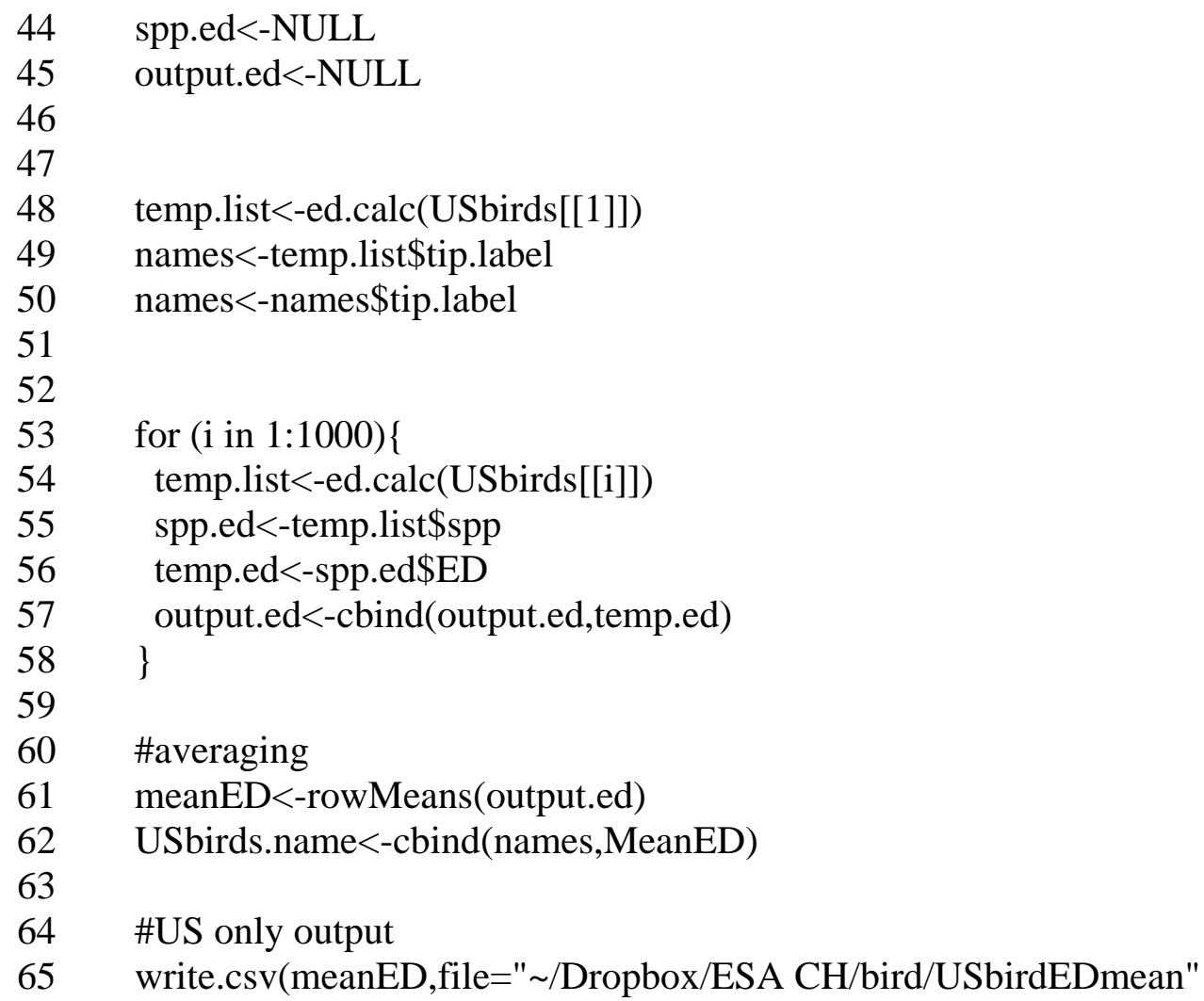




\section{B.1 Full RED-E mammal calculation}

Ranked priority of mammal species or populations for conservation according to RED-E. Those species’ EDGE score and rank are shown along with the change in rank (EDGE rank - RED-E rank).

\begin{tabular}{|c|c|c|c|c|c|}
\hline Mammal Species & $\begin{array}{c}\text { RED- } \\
\text { E } \\
\text { Rank }\end{array}$ & $\begin{array}{l}\text { RED- } \\
\text { E } \\
\text { Score } \\
\end{array}$ & $\begin{array}{c}\text { EDGE } \\
\text { Rank }\end{array}$ & $\begin{array}{l}\text { EDGE } \\
\text { Score }\end{array}$ & $\begin{array}{c}\text { EDGE } \\
\text { to RED- } \\
\text { E Rank } \\
\text { Change }\end{array}$ \\
\hline $\begin{array}{l}\text { Trichechus manatus } \\
\text { West Indian manatee }\end{array}$ & 1 & 7.41 & 3 & 5.15 & +2 \\
\hline $\begin{array}{r}\text { Zapus hudsonius luteus } \\
\text { New Mexico meadow jumping mouse }\end{array}$ & 2 & 7.08 & 52 & 2.49 & +50 \\
\hline $\begin{array}{r}\text { Aplodontia rufa nigra } \\
\text { Point Arena mountain beaver }\end{array}$ & 3 & 6.87 & 12 & 4.09 & +9 \\
\hline $\begin{array}{r}\text { Physeter catodon } \\
\text { sperm whale }\end{array}$ & 4 & 6.55 & 4 & 5.14 & 0 \\
\hline $\begin{array}{r}\text { Eubalaena glacialis } \\
\text { North Atlantic Right whale }\end{array}$ & 5 & 6.42 & 6 & 4.93 & +1 \\
\hline $\begin{array}{r}\text { Antilocapra americana sonoriensis } \\
\text { Sonoran pronghorn }\end{array}$ & 6 & 6.35 & 24 & 3.22 & +18 \\
\hline $\begin{array}{r}\text { Brachylagus idahoensis } \\
\text { pygmy rabbit }\end{array}$ & 7 & 6.23 & 20 & 3.26 & +13 \\
\hline $\begin{array}{l}\text { Ovis canadensis nelsoni } \\
\text { Peninsular bighorn sheep }\end{array}$ & 8 & 6.18 & 63 & 2.10 & +55 \\
\hline $\begin{array}{r}\text { Ovis canadensis sierrae } \\
\text { Sierra Nevada bighorn sheep }\end{array}$ & 8 & 6.18 & 63 & 2.10 & +55 \\
\hline
\end{tabular}




\begin{tabular}{|c|c|c|c|c|c|}
\hline $\begin{array}{r}\text { Sylvilagus bachmani riparius } \\
\text { riparian brush rabbit }\end{array}$ & 10 & 6.06 & 44 & 2.74 & +34 \\
\hline $\begin{array}{r}\text { Herpailurus yagouaroundi cacomitli } \\
\text { Gulf Coast jaguarundi }\end{array}$ & 11 & 6.00 & 31 & 2.84 & +20 \\
\hline $\begin{array}{r}\text { Herpailurus yagouaroundi tolteca } \\
\text { Sinaloan Jaguarundi }\end{array}$ & 11 & 6.00 & 31 & 2.84 & +20 \\
\hline $\begin{array}{r}\text { Puma concolor coryi } \\
\text { Flordia panther }\end{array}$ & 11 & 6.00 & 31 & 2.84 & +20 \\
\hline $\begin{array}{r}\text { Puma concolor couguar } \\
\text { Eastern cougar }\end{array}$ & 11 & 6.00 & 31 & 2.84 & +20 \\
\hline $\begin{array}{r}\text { Balaenoptera musculus } \\
\text { blue whale }\end{array}$ & 15 & 5.99 & 1 & 5.24 & -14 \\
\hline $\begin{array}{r}\text { Balaenoptera physalus } \\
\text { finback whale }\end{array}$ & 15 & 5.99 & 1 & 5.24 & -14 \\
\hline $\begin{array}{r}\text { Megaptera novaeangliae } \\
\text { humpback whale }\end{array}$ & 15 & 5.99 & 25 & 3.16 & +10 \\
\hline $\begin{array}{r}\text { Rangifer tarandus caribou } \\
\text { woodland caribou }\end{array}$ & 18 & 5.93 & 39 & 2.76 & +21 \\
\hline $\begin{array}{r}\text { Leopardus pardalis } \\
\text { Ocelot }\end{array}$ & 19 & 5.92 & 55 & 2.40 & +36 \\
\hline $\begin{array}{r}\text { Panthera onca } \\
\text { Jaguar }\end{array}$ & 20 & 5.92 & 28 & 2.94 & +8 \\
\hline $\begin{array}{r}\text { Leptonycteris curasoae yerbabuenae } \\
\text { lesser long-nosed bat }\end{array}$ & 21 & 5.90 & 15 & 3.92 & -6 \\
\hline $\begin{array}{r}\text { Leptonycteris nivalis } \\
\text { Mexican long-nosed bat }\end{array}$ & 21 & 5.90 & 7 & 4.62 & -14 \\
\hline $\begin{array}{r}\text { Balaenoptera borealis } \\
\text { Sei whale }\end{array}$ & 23 & 5.83 & 5 & 5.07 & -18 \\
\hline
\end{tabular}




\begin{tabular}{|c|c|c|c|c|c|}
\hline $\begin{array}{r}\text { Eumetopias jubatus } \\
\text { stellar sea lion }\end{array}$ & 24 & 5.73 & 27 & 3.02 & +3 \\
\hline $\begin{array}{l}\text { Glaucomys sabrinus coloratus } \\
\text { Carolina northern flying Squirrel }\end{array}$ & 25 & 5.73 & 54 & 2.45 & +29 \\
\hline $\begin{array}{r}\text { Neotoma fuscipes riparia } \\
\text { riparian woodrat }\end{array}$ & 26 & 5.72 & 36 & 2.83 & +10 \\
\hline $\begin{array}{r}\text { Odocoileus virginianus clavium } \\
\text { key deer }\end{array}$ & 27 & 5.72 & 66 & 1.96 & +39 \\
\hline $\begin{array}{l}\text { Odocoileus virginianus leucurus } \\
\text { Columbian white-tailed deer }\end{array}$ & 27 & 5.72 & 66 & 1.96 & +39 \\
\hline $\begin{array}{l}\text { Zapus hudsonius preblei } \\
\text { Preble's meadow jumping mouse }\end{array}$ & 29 & 5.69 & 52 & 2.49 & +23 \\
\hline $\begin{array}{r}\text { Corynorhinus townsendii ingens } \\
\text { Ozark big-eared bat }\end{array}$ & 30 & 5.68 & 57 & 2.35 & +27 \\
\hline $\begin{array}{r}\text { Plecotus townsendii virginianus } \\
\text { Virginia big-eared bat }\end{array}$ & 30 & 5.68 & 57 & 2.35 & +27 \\
\hline $\begin{array}{r}\text { Mustela nigripes } \\
\text { black-footed ferret }\end{array}$ & 32 & 5.63 & 14 & 3.93 & -18 \\
\hline $\begin{array}{l}\text { Sylvilagus palustris hefneri } \\
\text { Lower Keys marsh rabbit }\end{array}$ & 33 & 5.58 & 62 & 2.13 & +29 \\
\hline $\begin{array}{r}\text { Myotis sodalis } \\
\text { Indiana bat }\end{array}$ & 34 & 5.56 & 16 & 3.91 & -18 \\
\hline $\begin{array}{r}\text { Lasiurus cinereus semotus } \\
\text { Hawaiian hoary bat }\end{array}$ & 35 & 5.48 & 60 & 2.20 & +25 \\
\hline $\begin{array}{r}\text { Tamiasciurus hudsonicus grahamensis } \\
\text { Mount Graham red squirrel }\end{array}$ & 36 & 5.48 & 59 & 2.20 & +23 \\
\hline $\begin{array}{l}\text { Urocyon littoralis catalinae } \\
\text { Santa Catalina Island fox }\end{array}$ & 37 & 5.46 & 40 & 2.74 & +3 \\
\hline
\end{tabular}




\begin{tabular}{|c|c|c|c|c|c|}
\hline $\begin{array}{l}\text { Urocyon littoralis littoralis } \\
\text { San Miguel Island fox }\end{array}$ & 37 & 5.46 & 40 & 2.74 & +3 \\
\hline $\begin{array}{r}\text { Urocyon littoralis santacruzae } \\
\text { Santa Cruz Island fox }\end{array}$ & 37 & 5.46 & 40 & 2.74 & +3 \\
\hline $\begin{array}{r}\text { Urocyon littoralis santarosae } \\
\text { Santa Rosa Island fox }\end{array}$ & 37 & 5.46 & 43 & 2.74 & +6 \\
\hline $\begin{array}{r}\text { Reithrodontomys raviventris } \\
\text { salt marsh harvest mouse }\end{array}$ & 41 & 5.35 & 9 & 4.19 & -32 \\
\hline $\begin{array}{r}\text { Canis lupus } \\
\text { gray wolf }\end{array}$ & 42 & 5.33 & 75 & 1.43 & +33 \\
\hline $\begin{array}{l}\text { Canis lupus baileyi } \\
\text { Mexican gray wolf }\end{array}$ & 42 & 5.33 & 75 & 1.43 & +33 \\
\hline $\begin{array}{l}\text { Canis rufus } \\
\text { red wolf }\end{array}$ & 42 & 5.33 & 8 & 4.21 & -34 \\
\hline $\begin{array}{r}\text { Sciurus niger cinereus } \\
\text { Delmarva Peninsula fox squirrel }\end{array}$ & 45 & 5.25 & 71 & 1.60 & +26 \\
\hline $\begin{array}{r}\text { Perognathus longimembris pacificus } \\
\text { Pacific pocket mouse }\end{array}$ & 46 & 5.25 & 56 & 2.35 & +10 \\
\hline $\begin{array}{r}\text { Myotis grisescens } \\
\text { gray bat }\end{array}$ & 47 & 5.14 & 65 & 2.10 & +18 \\
\hline $\begin{array}{r}\text { Sorex ornatus relictus } \\
\text { Buena Vista Lake ornate shrew }\end{array}$ & 48 & 5.13 & 68 & 1.93 & +20 \\
\hline $\begin{array}{r}\text { Neotoma floridana smalli } \\
\text { Key Largo woodrat }\end{array}$ & 49 & 5.01 & 72 & 1.55 & +23 \\
\hline $\begin{array}{l}\text { Dipodomys ingens } \\
\text { giant kangaroo rat }\end{array}$ & 50 & 5.00 & 13 & 3.98 & -37 \\
\hline $\begin{array}{r}\text { Microtus mexicanus hualpaiensis } \\
\text { Hualapai Mexican vole }\end{array}$ & 51 & 4.99 & 73 & 1.52 & +22 \\
\hline
\end{tabular}




\begin{tabular}{|c|c|c|c|c|c|}
\hline $\begin{array}{r}\text { Microtus californicus scirpensis } \\
\text { Amargosa vole }\end{array}$ & 52 & 4.94 & 69 & 1.90 & +17 \\
\hline $\begin{array}{r}\text { Bison bison athabascae } \\
\text { wood bison }\end{array}$ & 53 & 4.94 & 29 & 2.89 & -24 \\
\hline $\begin{array}{l}\text { Ursus americanus } \\
\text { American black bear }\end{array}$ & 54 & 4.93 & 37 & 2.83 & -17 \\
\hline $\begin{array}{r}\text { Ursus americanus luteolus } \\
\text { Louisiana black bear }\end{array}$ & 54 & 4.93 & 37 & 2.83 & -17 \\
\hline $\begin{array}{r}\text { Ursus arctos horribilis } \\
\text { grizzly bear }\end{array}$ & 54 & 4.93 & 49 & 2.65 & -5 \\
\hline $\begin{array}{r}\text { Ursus arctos horribilis } \\
\text { grizzly bear }\end{array}$ & 54 & 4.93 & 49 & 2.65 & -5 \\
\hline $\begin{array}{r}\text { Ursus arctos horribilis } \\
\text { grizzly bear }\end{array}$ & 54 & 4.93 & 49 & 2.65 & -5 \\
\hline $\begin{array}{r}\text { Microtus pennsylvanicus dukecampbelli } \\
\text { Florida salt marsh vole }\end{array}$ & 59 & 4.92 & 70 & 1.86 & +11 \\
\hline $\begin{array}{r}\text { Dipodomys merriami parvus } \\
\text { San Bernardino Merriam's kangaroo rat }\end{array}$ & 60 & 4.84 & 21 & 3.25 & -39 \\
\hline $\begin{array}{r}\text { Dipodomys nitratoides exilis } \\
\text { Fresno kangaroo rat }\end{array}$ & 60 & 4.84 & 21 & 3.25 & -39 \\
\hline $\begin{array}{r}\text { Dipodomys nitratoides nitratoides } \\
\text { Tipton kangaroo rat }\end{array}$ & 60 & 4.84 & 21 & 3.25 & -39 \\
\hline $\begin{array}{r}\text { Peromyscus gossypinus allapaticola } \\
\text { Key Largo cotton mouse }\end{array}$ & 63 & 4.82 & 77 & 0.55 & +14 \\
\hline $\begin{array}{r}\text { Peromyscus polionotus allophrys } \\
\text { Choctawhatchee beach mouse }\end{array}$ & 63 & 4.82 & 77 & 0.55 & +14 \\
\hline $\begin{array}{r}\text { Peromyscus polionotus ammobates } \\
\text { Alabama beach mouse }\end{array}$ & 63 & 4.82 & 77 & 0.55 & +14 \\
\hline
\end{tabular}




\begin{tabular}{|c|c|c|c|c|}
\hline $\begin{array}{r}\text { Peromyscus polionotus peninsularis } \\
\text { St. Andrew beach mouse }\end{array}$ & 63 & 4.82 & 77 & 0.55 \\
\hline $\begin{array}{l}\text { Peromyscus polionotus phasma } \\
\text { Anastasia Island beach mouse }\end{array}$ & 63 & 4.82 & 77 & 0.55 \\
\hline $\begin{array}{r}\text { Peromyscus polionotus trissyllepsis } \\
\text { Perdido key beach mouse }\end{array}$ & 63 & 4.82 & 83 & 0.55 \\
\hline $\begin{array}{r}\text { Dipodomys heermanni morroensis } \\
\text { Morro Bay kangaroo rat }\end{array}$ & 69 & 4.72 & 26 & 3.14 \\
\hline $\begin{array}{l}\text { Dipodomys stephensi } \\
\text { Stephens' kangaroo rat }\end{array}$ & 69 & 4.72 & 18 & 3.84 \\
\hline $\begin{array}{l}\text { Puma concolor } \\
\text { moutnain lion }\end{array}$ & 71 & 4.61 & 31 & 2.84 \\
\hline $\begin{array}{r}\text { Lynx canadensis } \\
\text { Canada lynx }\end{array}$ & 72 & 4.46 & 61 & 2.17 \\
\hline $\begin{array}{l}\text { Enhydra lutris kenyoni } \\
\text { Northern sea otter }\end{array}$ & 73 & 4.36 & 10 & 4.12 \\
\hline $\begin{array}{l}\text { Enhydra lutris nereis } \\
\text { Southern sea otter }\end{array}$ & 73 & 4.36 & 10 & 4.12 \\
\hline $\begin{array}{r}\text { Arctocephalus townsendi } \\
\text { Guadalupe fur seal }\end{array}$ & 75 & 4.27 & 30 & 2.84 \\
\hline $\begin{array}{l}\text { Thomomys mazama glacialis } \\
\text { Roy Prairie pocket gopher }\end{array}$ & 76 & 4.18 & 45 & 2.71 \\
\hline $\begin{array}{r}\text { Thomomys mazama pugetensis } \\
\text { Olympia pocket gopher }\end{array}$ & 76 & 4.18 & 45 & 2.71 \\
\hline $\begin{array}{l}\text { Thomomys mazama tumuli } \\
\text { Tenino pocket gopher }\end{array}$ & 76 & 4.18 & 45 & 2.71 \\
\hline $\begin{array}{r}\text { Thomomys mazama yelmensis } \\
\text { Yelm pocket gopher }\end{array}$ & 76 & 4.18 & 48 & 2.71 \\
\hline
\end{tabular}




$\begin{array}{rlllll}\begin{array}{r}\text { Canis lupus } \\ \text { gray wolf }\end{array} & 80 & 3.94 & 75 & 1.43 & -5 \\ \begin{array}{r}\text { Peromyscus polionotus niveiventris } \\ \text { Southeastern beach mouse }\end{array} & 81 & 3.43 & 82 & 0.55 & +1 \\ \begin{array}{r}\text { Spermophilus brunneus brunneus } \\ \text { Northern Idaho ground squirrel }\end{array} & 82 & 3.41 & 17 & 3.91 & -65 \\ \begin{array}{r}\text { Cynomys parvidens } \\ \text { Utah prairie dog }\end{array} & 83 & 3.33 & 19 & 3.81 & -64\end{array}$




\section{B.2 Full RED-E bird calculation}

Ranked priority of bird species or populations for conservation according to RED-E. Those species’ EDGE score and rank are shown along with the change in rank (EDGE rank - RED-E rank).

\begin{tabular}{|c|c|c|c|c|c|}
\hline Bird Species & $\begin{array}{c}\text { RED- } \\
\text { E } \\
\text { Rank }\end{array}$ & $\begin{array}{l}\text { RED- } \\
\text { E } \\
\text { Score }\end{array}$ & $\begin{array}{c}\text { EDG } \\
\text { E } \\
\text { Rank }\end{array}$ & $\begin{array}{c}\text { EDG } \\
\text { E } \\
\text { Score }\end{array}$ & $\begin{array}{c}\text { EDGE } \\
\text { to RED- } \\
\text { E Rank } \\
\text { Change }\end{array}$ \\
\hline $\begin{array}{l}\text { Campephilus principalis } \\
\text { ivory-billed woodpecker }\end{array}$ & 1 & 6.27 & 2 & 5.02 & +1 \\
\hline $\begin{array}{r}\text { Gymnogyps californianus } \\
\text { California condor }\end{array}$ & 2 & 6.11 & 1 & 5.59 & -1 \\
\hline $\begin{array}{l}\text { Gallinula chloropus guami } \\
\text { Mariana common moorhen }\end{array}$ & 3 & 6.02 & 24 & 2.28 & +21 \\
\hline $\begin{array}{l}\text { Gallinula chloropus sandvicensis } \\
\text { Hawaiian common moorhen }\end{array}$ & 3 & 6.02 & 24 & 2.28 & +21 \\
\hline $\begin{array}{r}\text { Rostrhamus sociabilis plumbeus } \\
\text { Everglade snail kite }\end{array}$ & 5 & 6.01 & 30 & 2.18 & +25 \\
\hline $\begin{array}{r}\text { Charadrius melodus } \\
\text { piping plover }\end{array}$ & 6 & 6.00 & 12 & 3.24 & +6 \\
\hline $\begin{array}{r}\text { Grus canadensis pulla } \\
\text { Mississippi sandhill crane }\end{array}$ & 7 & 5.99 & 23 & 2.46 & +16 \\
\hline $\begin{array}{r}\text { Himantopus mexicanus knudseni } \\
\text { Hawaiian stilt }\end{array}$ & 8 & 5.94 & 26 & 2.25 & +18 \\
\hline Rhynchopsitta pachyrhyncha & 9 & 5.88 & 5 & 4.23 & -4 \\
\hline
\end{tabular}


thick-billed Parrot

Buteo platypterus brunnescens Puerto Rican broad-winged hawk

Accipiter striatus venator

Puerto Rican sharp-shinned hawk

Rallus longirostris levipes

light-footed clapper rail

Rallus longirostris obsoletus

California clapper rail

Rallus longirostris yumanensis

Yuma clapper rail

Grus americana

whooping crane

Fulica americana alai

Hawaiian coot

Picoides borealis

red-cockaded woodpecker

Falco femoralis septentrionalis

Northern aplomado falcon

Colinus virginianus ridgwayi

masked bobwhite

Lanius ludovicianus mearnsi

San Clemente loggerhead shrike

Vireo atricapilla

black-capped vireo

Vireo bellii pusillus

least Bell's vireo

Empidonax traillii extimus

$\begin{array}{lllll}10 & 5.83 & 20 & 2.54 & +10 \\ 11 & 5.82 & 22 & 2.48 & +11 \\ 12 & 5.78 & 34 & 2.05 & +22 \\ 12 & 5.78 & 34 & 2.05 & +22 \\ 12 & 5.78 & 34 & 2.05 & +22 \\ 15 & 5.75 & 3 & 4.54 & -12 \\ 16 & 5.68 & 28 & 2.23 & +12 \\ 17 & 5.54 & 9 & 3.68 & -8 \\ 18 & 5.47 & 29 & 2.22 & +11 \\ 19 & 5.47 & 18 & 2.78 & -1 \\ 20 & 5.16 & 27 & 2.24 & +7 \\ 21 & 5.15 & 8 & 3.77 & -13 \\ 22 & 5.12 & 14 & 2.98 & -8 \\ & 5.08 & 40 & 1.97 & +17\end{array}$


Southwestern willow flycatcher

Dendroica chrysoparia golden-cheeked warbler

Ammodramus savannarum floridanus

Florida grasshopper sparrow

Mycteria americana wood stork

Charadrius alexandrinus nivosus Western snowy plover

Ammodramus maritimus mirabilis

Cape Sabale seaside sparow

Strix occidentalis caurina

Northern spotted owl

Strix occidentalis lucida

Mexican spotted owl

Charadrius melodus piping plover

Sterna antillarum least tern

Sterna antillarum browni

California least tern

Sterna dougallii dougallii

roseate tern

Calidris canutus rufa red knot

Eremophila alpestris strigata streaked horned lark $\begin{array}{lllll}24 & 4.95 & 6 & 4.12 & -18\end{array}$

$\begin{array}{lllll}25 & 4.81 & 41 & 1.88 & +16\end{array}$

$\begin{array}{lllll}26 & 4.75 & 17 & 2.82 & -9\end{array}$

$\begin{array}{lllll}27 & 4.69 & 21 & 2.49 & -6\end{array}$

$\begin{array}{lllll}28 & 4.67 & 43 & 1.77 & +15\end{array}$

$\begin{array}{lllll}29 & 4.67 & 15 & 2.93 & -14\end{array}$

$\begin{array}{lllll}29 & 4.67 & 15 & 2.93 & -14\end{array}$

$\begin{array}{lllll}31 & 4.62 & 12 & 3.24 & -19\end{array}$

$\begin{array}{lllll}32 & 4.56 & 37 & 1.99 & +5\end{array}$

$\begin{array}{lllll}32 & 4.56 & 37 & 1.99 & +5\end{array}$

$\begin{array}{lllll}34 & 4.52 & 32 & 2.16 & -2\end{array}$

$\begin{array}{lllll}35 & 4.45 & 19 & 2.61 & -16\end{array}$

$\begin{array}{lllll}36 & 4.38 & 39 & 1.97 & +3\end{array}$

$\begin{array}{llllll}\text { Polioptila californica californica } & 37 & 4.14 & 31 & 2.17 & -6\end{array}$ 


\begin{tabular}{|c|c|c|c|c|c|}
\hline $\begin{array}{r}\text { Aphelocoma coerulescens } \\
\text { Florida scrub-jay }\end{array}$ & 38 & 3.72 & 10 & 3.56 & -28 \\
\hline $\begin{array}{l}\text { Centrocercus minimus } \\
\text { Gunnison sage-grouse }\end{array}$ & 39 & 3.71 & 7 & 4.07 & -32 \\
\hline $\begin{array}{r}\text { Tympanuchus pallidicinctus } \\
\text { lesser prairie-chicken }\end{array}$ & 40 & 3.69 & 11 & 3.38 & -29 \\
\hline $\begin{array}{r}\text { Brachyramphus marmoratus } \\
\text { marbled murrelet }\end{array}$ & 41 & 3.58 & 4 & 4.42 & -37 \\
\hline $\begin{array}{r}\text { Amphispiza belli clementeae } \\
\text { San Clemente sage }\end{array}$ & 42 & 3.32 & 42 & 1.79 & 0 \\
\hline $\begin{array}{l}\text { Pipilo crissalis eremophilus } \\
\text { Inyo California towhee }\end{array}$ & 43 & 3.32 & 44 & 1.76 & +1 \\
\hline $\begin{array}{r}\text { Sterna dougallii dougallii } \\
\text { roseate tern }\end{array}$ & 44 & 3.13 & 32 & 2.16 & -12 \\
\hline
\end{tabular}


C.1 Sensitivity of mammal ranking to Threatened and Endangered values

Difference in ranks when assigning 'threatened' mammal species with a value of 0,1 , or 2 and 'endangered' species with a value of 1,2 , or 4 .

\begin{tabular}{|c|c|c|c|c|}
\hline Mammal Species & Status & $\begin{array}{c}\mathrm{T}=2 ; \mathrm{E}=4 \\
\text { Rank }\end{array}$ & $\begin{array}{c}\mathrm{T}=0,1 ; \\
\mathrm{E}=1,2 \\
\text { Rank }\end{array}$ & $\begin{array}{c}\text { LE Rank } \\
\text { Change }\end{array}$ \\
\hline $\begin{array}{r}\text { Trichechus manatus } \\
\text { West Indian manatee }\end{array}$ & $\mathrm{E}$ & 1 & 1 & 0 \\
\hline $\begin{array}{r}\text { Zapus hudsonius luteus } \\
\text { New Mexico meadow jumping mouse }\end{array}$ & $\mathrm{E}$ & 2 & 2 & 0 \\
\hline $\begin{array}{r}\text { Aplodontia rufa nigra } \\
\text { Point Arena mountain beaver }\end{array}$ & $\mathrm{E}$ & 3 & 3 & 0 \\
\hline $\begin{array}{r}\text { Physeter catodon } \\
\text { sperm whale }\end{array}$ & $\mathrm{E}$ & 4 & 4 & 0 \\
\hline $\begin{array}{r}\text { Eubalaena glacialis } \\
\text { North Atlantic Right whale }\end{array}$ & $\mathrm{E}$ & 5 & 5 & 0 \\
\hline $\begin{array}{r}\text { Antilocapra americana sonoriensis } \\
\text { Sonoran pronghorn }\end{array}$ & $\mathrm{E}$ & 6 & 7 & -1 \\
\hline $\begin{array}{r}\text { Brachylagus idahoensis } \\
\text { pygmy rabbit }\end{array}$ & $\mathrm{E}$ & 7 & 8 & -1 \\
\hline $\begin{array}{l}\text { Ovis canadensis nelsoni } \\
\text { Peninsular bighorn sheep }\end{array}$ & $\mathrm{E}$ & 8 & 9 & -1 \\
\hline $\begin{array}{r}\text { Ovis canadensis sierrae } \\
\text { Sierra Nevada bighorn sheep }\end{array}$ & $\mathrm{E}$ & 8 & 9 & -1 \\
\hline $\begin{array}{r}\text { Sylvilagus bachmani riparius } \\
\text { riparian brush rabbit }\end{array}$ & $\mathrm{E}$ & 10 & 11 & -1 \\
\hline Herpailurus yagouaroundi cacomitli & $\mathrm{E}$ & 11 & 12 & -1 \\
\hline
\end{tabular}


Gulf Coast jaguarundi

Herpailurus yagouaroundi tolteca

Sinaloan Jaguarundi

Puma concolor coryi

Flordia panther

Puma concolor couguar

Eastern cougar

Balaenoptera musculus

blue whale

Balaenoptera physalus

finback whale

Megaptera novaeangliae

humpback whale

Rangifer tarandus caribou

woodland caribou

Leopardus pardalis

Ocelot

Panthera onca

Jaguar

Leptonycteris curasoae yerbabuenae

lesser long-nosed bat

Leptonycteris nivalis

Mexican long-nosed bat

Balaenoptera borealis

Sei whale

Eumetopias jubatus

stellar sea lion

Glaucomys sabrinus coloratus

\begin{tabular}{|c|c|c|}
\hline $\mathrm{E}$ & 11 & 12 \\
\hline $\mathrm{E}$ & 11 & 12 \\
\hline $\mathrm{E}$ & 11 & 12 \\
\hline $\mathrm{E}$ & 15 & 16 \\
\hline $\mathrm{E}$ & 15 & 16 \\
\hline $\mathrm{E}$ & 15 & 16 \\
\hline $\mathrm{E}$ & 18 & 19 \\
\hline $\mathrm{E}$ & 19 & 20 \\
\hline $\mathrm{E}$ & 20 & 21 \\
\hline $\mathrm{E}$ & 21 & 22 \\
\hline $\mathrm{E}$ & 21 & 22 \\
\hline $\mathrm{E}$ & 23 & 24 \\
\hline $\mathrm{E}$ & 24 & 25 \\
\hline $\mathrm{E}$ & 25 & 26 \\
\hline
\end{tabular}


Carolina northern flying Squirrel Neotoma fuscipes riparia riparian woodrat

Odocoileus virginianus clavium key deer

Odocoileus virginianus leucurus Columbian white-tailed deer

Zapus hudsonius preblei Preble's meadow jumping mouse

Corynorhinus townsendii ingens Ozark big-eared bat

Plecotus townsendii virginianus Virginia big-eared bat Mustela nigripes black-footed ferret

Sylvilagus palustris hefneri Lower Keys marsh rabbit Myotis sodalis Indiana bat

Lasiurus cinereus semotus Hawaiian hoary bat

Tamiasciurus hudsonicus grahamensis

Mount Graham red squirrel

Urocyon littoralis catalinae Santa Catalina Island fox

Urocyon littoralis littoralis San Miguel Island fox

Urocyon littoralis santacruzae

E

E

E

E

E

E
29

30

30

30

33

39

40

41

42 
Santa Cruz Island fox Urocyon littoralis santarosae Santa Rosa Island fox

Reithrodontomys raviventris salt marsh harvest mouse

Canis lupus gray wolf

Canis lupus baileyi Mexican gray wolf

Canis rufus red wolf

Sciurus niger cinereus

Delmarva Peninsula fox squirrel

Perognathus longimembris pacificus

Pacific pocket mouse

Myotis grisescens gray bat

Sorex ornatus relictus

Buena Vista Lake ornate shrew

Neotoma floridana smalli

Key Largo woodrat

Dipodomys ingens

giant kangaroo rat

Microtus mexicanus hualpaiensis

Hualapai Mexican vole

Microtus californicus scirpensis

Amargosa vole

Bison bison athabascae

\begin{tabular}{|c|c|c|c|}
\hline $\mathrm{E}$ & 37 & 43 & -6 \\
\hline $\mathrm{E}$ & 41 & 47 & -6 \\
\hline $\mathrm{E}$ & 42 & 48 & -6 \\
\hline E & 42 & 48 & -6 \\
\hline E & 42 & 48 & -6 \\
\hline$E$ & 45 & 52 & -7 \\
\hline $\mathrm{E}$ & 46 & 53 & -7 \\
\hline $\mathrm{E}$ & 47 & 55 & -8 \\
\hline E & 48 & 56 & -8 \\
\hline E & 49 & 59 & -10 \\
\hline $\mathrm{E}$ & 50 & 60 & -10 \\
\hline$E$ & 51 & 61 & -1 \\
\hline$E$ & 52 & 63 & -1 \\
\hline $\mathrm{T}$ & 53 & 32 & +2 \\
\hline
\end{tabular}


wood bison

Ursus americanus

American black bear

Ursus americanus luteolus

Louisiana black bear

Ursus arctos horribilis grizzly bear

Ursus arctos horribilis grizzly bear

Ursus arctos horribilis grizzly bear

Microtus pennsylvanicus dukecampbelli

Florida salt marsh vole

Dipodomys merriami parvus San Bernardino Merriam's kangaroo rat

Dipodomys nitratoides exilis Fresno kangaroo rat

Dipodomys nitratoides nitratoides

Tipton kangaroo rat

Peromyscus gossypinus allapaticola

Key Largo cotton mouse

Peromyscus polionotus allophrys

Choctawhatchee beach mouse

Peromyscus polionotus ammobates

Alabama beach mouse

Peromyscus polionotus peninsularis

St. Andrew beach mouse

Peromyscus polionotus phasma

\begin{tabular}{|c|c|c|}
\hline SAT & 54 & 34 \\
\hline $\mathrm{T}$ & 54 & 34 \\
\hline $\mathrm{T}$ & 54 & 34 \\
\hline $\mathrm{T}$ & 54 & 34 \\
\hline $\mathrm{T}$ & 54 & 34 \\
\hline $\mathrm{E}$ & 59 & 64 \\
\hline $\mathrm{E}$ & 60 & 69 \\
\hline $\mathrm{E}$ & 60 & 69 \\
\hline $\mathrm{E}$ & 60 & 69 \\
\hline $\mathrm{E}$ & 63 & 72 \\
\hline $\mathrm{E}$ & 63 & 72 \\
\hline $\mathrm{E}$ & 63 & 72 \\
\hline $\mathrm{E}$ & 63 & 72 \\
\hline $\mathrm{E}$ & 63 & 72 \\
\hline
\end{tabular}


Anastasia Island beach mouse Peromyscus polionotus trissyllepsis Perdido key beach mouse

Dipodomys heermanni morroensis Morro Bay kangaroo rat

Dipodomys stephensi Stephens' kangaroo rat

Puma concolor mountain lion

Lynx canadensis

Canada lynx

Enhydra lutris kenyoni

Northern sea otter

Enhydra lutris nereis

Southern sea otter

Arctocephalus townsendi

Guadalupe fur seal

Thomomys mazama glacialis

Roy Prairie pocket gopher

Thomomys mazama pugetensis

Olympia pocket gopher

Thomomys mazama tumuli

Tenino pocket gopher

Thomomys mazama yelmensis

Yelm pocket gopher

Canis lupus

gray wolf

Peromyscus polionotus niveiventris

\begin{tabular}{|c|c|c|c|}
\hline $\mathrm{E}$ & 63 & 72 & -9 \\
\hline $\mathrm{E}$ & 69 & 78 & -9 \\
\hline $\mathrm{E}$ & 69 & 78 & -9 \\
\hline SAT & 71 & 51 & +20 \\
\hline $\mathrm{T}$ & 72 & 54 & +18 \\
\hline $\mathrm{T}$ & 73 & 57 & +16 \\
\hline $\mathrm{T}$ & 73 & 57 & +16 \\
\hline $\mathrm{T}$ & 75 & 62 & +13 \\
\hline $\mathrm{T}$ & 76 & 65 & +11 \\
\hline $\mathrm{T}$ & 76 & 65 & +11 \\
\hline $\mathrm{T}$ & 76 & 65 & +11 \\
\hline $\mathrm{T}$ & 76 & 65 & +11 \\
\hline $\mathrm{T}$ & 80 & 80 & 0 \\
\hline $\mathrm{T}$ & 81 & 81 & 0 \\
\hline
\end{tabular}


Southeastern beach mouse Spermophilus brunneus brunneus Northern Idaho ground squirrel Cynomys parvidens

Utah prairie dog 


\section{C.2 Sensitivity of bird ranking to Threatened and Endangered values}

Difference in ranks when assigning 'threatened' bird species with a value of 0 , 1, or 2 and 'endangered' species with a value of 1 , 2, or 4 .

\begin{tabular}{|c|c|c|c|c|}
\hline Bird Species & Status & $\begin{array}{c}\mathrm{T}=2 ; \mathrm{E}=4 \\
\text { Rank }\end{array}$ & $\begin{array}{l}\mathrm{T}=0,1 ; \\
\mathrm{E}=1,2 \\
\text { Rank }\end{array}$ & $\begin{array}{c}\text { LE Rank } \\
\text { Change }\end{array}$ \\
\hline $\begin{array}{l}\text { Campephilus principalis } \\
\text { ivory-billed woodpecker }\end{array}$ & $\mathrm{E}$ & 10 & 10 & 0 \\
\hline $\begin{array}{r}\text { Gymnogyps californianus } \\
\text { California condor }\end{array}$ & $\mathrm{E}$ & 8 & 8 & 0 \\
\hline $\begin{array}{l}\text { Gallinula chloropus guami } \\
\text { Mariana common moorhen }\end{array}$ & $\mathrm{E}$ & 2 & 2 & 0 \\
\hline $\begin{array}{l}\text { Gallinula chloropus sandvicensis } \\
\text { Hawaiian common moorhen }\end{array}$ & E & 4 & 4 & 0 \\
\hline $\begin{array}{r}\text { Rostrhamus sociabilis plumbeus } \\
\text { Everglade snail kite }\end{array}$ & $\mathrm{E}$ & 29 & 36 & -7 \\
\hline $\begin{array}{r}\text { Charadrius melodus } \\
\text { piping plover }\end{array}$ & $\mathrm{E}$ & 11 & 11 & 0 \\
\hline $\begin{array}{l}\text { Grus canadensis pulla } \\
\text { Mississippi sandhill crane }\end{array}$ & $\mathrm{E}$ & 5 & 5 & 0 \\
\hline $\begin{array}{r}\text { Himantopus mexicanus knudseni } \\
\text { Hawaiian stilt }\end{array}$ & $\mathrm{E}$ & 18 & 22 & -4 \\
\hline $\begin{array}{r}\text { Rhynchopsitta pachyrhyncha } \\
\text { thick-billed Parrot }\end{array}$ & $\mathrm{E}$ & 25 & 35 & -10 \\
\hline
\end{tabular}


Buteo platypterus brunnescens Puerto Rican broad-winged hawk

Accipiter striatus venator

Puerto Rican sharp-shinned hawk

Rallus longirostris levipes

light-footed clapper rail

Rallus longirostris obsoletus

California clapper rail

Rallus longirostris yumanensis

Yuma clapper rail

Grus americana

whooping crane

Fulica americana alai

Hawaiian coot

Picoides borealis

red-cockaded woodpecker

Falco femoralis septentrionalis

Northern aplomado falcon

Colinus virginianus ridgwayi

$$
\text { masked bobwhite }
$$

Lanius ludovicianus mearnsi

San Clemente loggerhead shrike

Vireo atricapilla

black-capped vireo

Vireo bellii pusillus

least Bell's vireo

Empidonax traillii extimus

Southwestern willow flycatcher

\begin{tabular}{|c|c|c|c|}
\hline $\mathrm{E}$ & 9 & 9 & 0 \\
\hline $\mathrm{E}$ & 1 & 1 & 0 \\
\hline $\mathrm{E}$ & 22 & 31 & -9 \\
\hline $\mathrm{E}$ & 15 & 15 & 0 \\
\hline $\mathrm{E}$ & 23 & 33 & -10 \\
\hline $\mathrm{E}$ & 5 & 5 & 0 \\
\hline $\mathrm{E}$ & 17 & 17 & 0 \\
\hline $\mathrm{E}$ & 20 & 27 & -7 \\
\hline E & 16 & 16 & 0 \\
\hline $\mathrm{E}$ & 11 & 11 & 0 \\
\hline $\mathrm{E}$ & 19 & 23 & -4 \\
\hline $\mathrm{E}$ & 24 & 34 & -10 \\
\hline E & 32 & 38 & -6 \\
\hline $\mathrm{E}$ & 14 & 14 & 0 \\
\hline
\end{tabular}




\begin{tabular}{|c|c|c|c|c|}
\hline $\begin{array}{r}\text { Dendroica chrysoparia } \\
\text { golden-cheeked warbler }\end{array}$ & $E$ & 13 & 13 & 0 \\
\hline $\begin{array}{r}\text { Ammodramus savannarum floridanus } \\
\text { Florida grasshopper sparrow }\end{array}$ & $E$ & 7 & 7 & 0 \\
\hline $\begin{array}{r}\text { Mycteria americana } \\
\text { wood stork }\end{array}$ & $\mathrm{T}$ & 34 & 24 & +10 \\
\hline $\begin{array}{r}\text { Charadrius alexandrinus nivosus } \\
\text { Western snowy plover }\end{array}$ & $\mathrm{T}$ & 36 & 26 & +10 \\
\hline $\begin{array}{l}\text { Ammodramus maritimus mirabilis } \\
\text { Cape Sabale seaside sparrow }\end{array}$ & $E$ & 3 & 3 & 0 \\
\hline $\begin{array}{l}\text { Strix occidentalis caurina } \\
\text { Northern spotted owl }\end{array}$ & $\mathrm{T}$ & 42 & 42 & 0 \\
\hline $\begin{array}{l}\text { Strix occidentalis lucida } \\
\text { Mexican spotted owl }\end{array}$ & $\mathrm{T}$ & 43 & 43 & 0 \\
\hline $\begin{array}{r}\text { Charadrius melodus } \\
\text { piping plover }\end{array}$ & $\mathrm{T}$ & 37 & 29 & +8 \\
\hline $\begin{array}{r}\text { Sterna antillarum } \\
\text { least tern }\end{array}$ & $E$ & 29 & 36 & -7 \\
\hline $\begin{array}{r}\text { Sterna antillarum browni } \\
\text { California least tern }\end{array}$ & E & 32 & 38 & -6 \\
\hline $\begin{array}{r}\text { Sterna dougallii dougallii } \\
\text { roseate tern }\end{array}$ & $E$ & 21 & 28 & -7 \\
\hline $\begin{array}{r}\text { Calidris canutus rufa } \\
\text { red knot }\end{array}$ & $\mathrm{T}$ & 31 & 21 & +10 \\
\hline $\begin{array}{r}\text { Eremophila alpestris strigata } \\
\text { streaked horned lark }\end{array}$ & $\mathrm{T}$ & 39 & 32 & +7 \\
\hline $\begin{array}{r}\text { Polioptila californica californica } \\
\text { coastal California gnatcatcher }\end{array}$ & $\mathrm{T}$ & 38 & 30 & +8 \\
\hline
\end{tabular}




\begin{tabular}{|c|c|c|c|c|}
\hline $\begin{array}{r}\text { Aphelocoma coerulescens } \\
\text { Florida scrub-jay }\end{array}$ & $\mathrm{T}$ & 27 & 19 & +8 \\
\hline $\begin{array}{l}\text { Centrocercus minimus } \\
\text { Gunnison sage-grouse }\end{array}$ & $\mathrm{T}$ & 34 & 24 & +10 \\
\hline $\begin{array}{r}\text { Tympanuchus pallidicinctus } \\
\text { lesser prairie-chicken }\end{array}$ & $\mathrm{T}$ & 44 & 44 & 0 \\
\hline $\begin{array}{r}\text { Brachyramphus marmoratus } \\
\text { marbled murrelet }\end{array}$ & $\mathrm{T}$ & 28 & 20 & +8 \\
\hline $\begin{array}{r}\text { Amphispiza belli clementeae } \\
\text { San Clemente sage }\end{array}$ & $\mathrm{T}$ & 26 & 18 & +8 \\
\hline $\begin{array}{l}\text { Pipilo crissalis eremophilus } \\
\text { Inyo California towhee }\end{array}$ & $\mathrm{T}$ & 41 & 41 & 0 \\
\hline $\begin{array}{r}\text { Sterna dougallii dougallii } \\
\text { roseate tern }\end{array}$ & $\mathrm{T}$ & 40 & 40 & 0 \\
\hline
\end{tabular}

